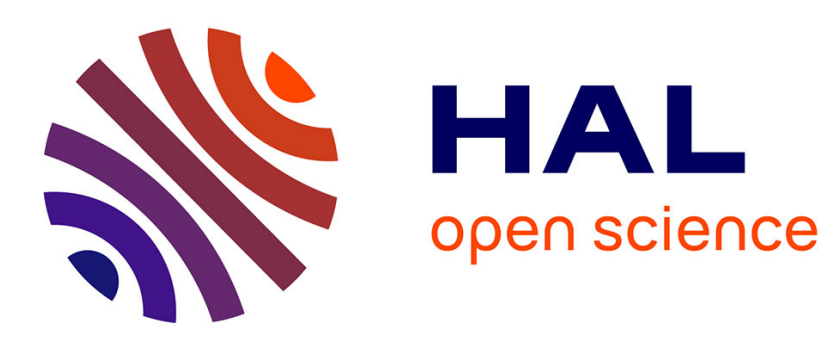

\title{
Timing of Cache Creek Ocean closure: insights from new Jurassic radiolarian ages in British Columbia and Yukon and their significance for Canadian Cordillera tectonics
}

Fabrice Cordey

\section{- To cite this version:}

Fabrice Cordey. Timing of Cache Creek Ocean closure: insights from new Jurassic radiolarian ages in British Columbia and Yukon and their significance for Canadian Cordillera tectonics. Canadian journal of earth sciences, 2020, 57 (10), pp.1167-1179. 10.1139/cjes-2019-0236 . hal-03271659

\author{
HAL Id: hal-03271659 \\ https://hal.science/hal-03271659
}

Submitted on 30 Jun 2021

HAL is a multi-disciplinary open access archive for the deposit and dissemination of scientific research documents, whether they are published or not. The documents may come from teaching and research institutions in France or abroad, or from public or private research centers.
L'archive ouverte pluridisciplinaire HAL, est destinée au dépôt et à la diffusion de documents scientifiques de niveau recherche, publiés ou non, émanant des établissements d'enseignement et de recherche français ou étrangers, des laboratoires publics ou privés. 
1 Title: Timing of Cache Creek Ocean closure: insights from new Jurassic radiolarian ages in

2 British Columbia and Yukon, and their significance for Canadian Cordillera tectonics.

4 Author: Fabrice Cordey

5 Affiliation and address : Université de Lyon, Université Claude Bernard Lyon 1, Laboratoire de

6 Géologie de Lyon Terre Planètes Environnement LGLTPE, CNRS-UMR 5276, Bd du 11

7 Novembre 1918, 69622 Villeurbanne, France

$8 \quad$ Email: fabrice.cordey@univ-lyon1.fr

9 Phone: +33633527563

10

11 Short title: Jurassic radiolarian ages from the Cache Creek Terrane

17 Keywords: Cache Creek Terrane, Radiolaria, Jurassic, Canadian Cordillera, radiolarian chert, 18 Bridge River Terrane 
20 Title: Timing of Cache Creek Ocean closure: insights from new Jurassic radiolarian ages in

21 British Columbia and Yukon, and their significance for Canadian Cordillera tectonics.

23 Author: Fabrice Cordey

25 Abstract

26 The closure of the Cache Creek Ocean during the Jurassic led to the structuration of the Canadian

27 Cordillera. To reassess the timing of this major tectonic event, this study proposes a

28 biochronological review of all the youngest radiolarian-bearing localities of the Cache Creek

29 Terrane in British Columbia and Yukon using updated radiolarian biozonations and taxonomy,

30 complemented by new data from the type locality. The results show that all ages are Early

31 Jurassic and fairly homogenous along the entire terrane. All the youngest siliceous rocks are

32 restricted to the Late Sinemurian-Early Toarcian interval ( $195-180 \mathrm{Ma})$. The youngest well-

33 dated pelagic cherts are Early Pliensbachian, with slightly younger siliceous argillites of

34 Pliensbachian and possibly Early Toarcian age. These results suggest that Cache Creek deep

35 pelagic sedimentation ceased fairly synchronously along the entire belt, probably during the

36 Pliensbachian ( 191-183 Ma), predating the final closure of the basin when Cache Creek units

37 were thrust over Stikinia and Quesnellia in the Middle and Late Jurassic. This apparent

38 synchronicity should result in re-evaluating the tectonic mechanism of the Cache Creek

39 "entrapment model" in its present form. The study also shows that pelagic sedimentation ceased

4022 to 31 m.y. earlier in the Cache Creek Terrane than in the Bridge River Terrane, confirming the

41 stratigraphic discrepancy between the two terranes during the Jurassic. 


\section{Résumé}

43 La fermeture de l'océan Cache Creek au Jurassique a conduit à la structuration de la Cordillère

44 Canadienne. Afin de réévaluer la chronologie de cet événement tectonique majeur, l'étude

45 propose une synthèse biochronologique de toutes les plus jeunes localités à radiolaires du terrane

46 de Cache Creek en Colombie-Britannique et au Yukon grâce aux nouvelles biozonations et à une

47 taxonomie actualisée, avec en complément de nouvelles données pour la localité-type. Les

48 résultats montrent que tous les âges sont du Jurassique inférieur et sont homogènes pour

49 l'ensemble du terrane. Toutes les roches siliceuses les plus jeunes sont comprises dans l'intervalle

50 Sinémurien supérieur-Toarcien inférieur ( 195-180 Ma). Les plus jeunes cherts pélagiques sont

51 du Pliensbachien inférieur, avec des argilites siliceuses légèrement plus jeunes du Pliensbachien

52 et peut-être du Toarcien inférieur. Ces résultats suggèrent que la sédimentation pélagique

53 profonde de l'océan Cache Creek a cessé de manière relativement synchrone sur toute sa

54 longueur, probablement pendant le Pliensbachien ( 191-183 Ma), avant la fermeture finale du

55 bassin lorsque les unités de Cache Creek ont été charriées sur la Stikinia et la Quesnellia au

56 Jurassique moyen et supérieur. Ce synchronisme apparent devrait conduire à réévaluer les

57 modalités du modèle tectonique en ciseau sous sa forme actuelle. L'étude montre aussi que la

58 sédimentation pélagique a cessé 22 à 31 Ma plus tôt dans le terrane de Cache Creek que dans

59 celui de Bridge River, confirmant la différence stratigraphique entre les deux unités au

60 Jurassique.

61

62 Mots-clés : terrane de Cache Creek, Radiolaria, Jurassique, Cordillère canadienne, radiolarite, 63 terrane de Bridge River 
67 The Canadian Cordillera (Fig. 1) is a complex collage of arc and oceanic terranes which has been 68 the subject of a vast amount of studies and literature in the past 50 years. Various models 69 describing the tectonic history of the orogen are still debated (Monger \& Gibson 2019 and 70 references therein) but they all point to the importance of the Cache Creek Terrane, considered as 71 one major evidence for a large Mesozoic ocean basin in the Canadian Cordillera. One important

72 issue is the timing of the ocean closure during the Jurassic period which led to collision with

73 Stikinia and Quesnellia volcanic arcs, contributing to the structuration of the Cordillera (Nelson 74 and Mihalynuk 1993, Colpron et al. 2015, Monger \& Gibson 2019).

75 To determine the age of the Cache Creek Terrane, radiolarian biostratigraphy has been applied 76 over the last 40 years to its deep ocean strata with a particular focus on the youngest localities 77 considered to predate the final stages of convergence. The youngest Jurassic unit of the Cache 78 Creek Terrane was originally found in its type locality in southern British Columbia (Cordey et al. 1987). At the time, it contradicted the scenario in which amalgamation of the Cache Creek and

80 Quesnellia terranes occurred in the Late Triassic (Monger 1981, Monger et al. 1982). Further investigations confirmed the occurrence of Jurassic radiolarian-bearing oceanic strata in all

82 segments of the Cache Creek Terrane in British Columbia and Yukon (Fig. 2; Cordey et al. 1991, 83 Cordey \& Struik 1996, Cordey 1998, Orchard et al. 2001, Struik et al. 2001, Mihalynuk et al. 2004). Although most of these localities are Early Jurassic, some confusion remained due to the

85 "Early or Middle Jurassic" age of the youngest Cache Creek rocks in the type locality. This question also led to conflicting interpretations in comparisons between the Cache Creek Terrane

87 and other Paleozoic-Mesozoic oceanic units of the Canadian Cordillera such as the Bridge River 88 and Hozameen terranes (Cordey et al. 1987, Cordey \& Schiarizza 1993, Mihalynuk et al. 1994, 89 Cordey 1998, Monger 2014). 
90 To clarify the stratigraphy of the youngest Cache Creek strata, the goal of this study is to review

91 all the youngest radiolarian localities and, when possible, improve and refine previous ages with

92 new Jurassic radiolarian biozonations and taxonomy (Baumgartner et al. 1995, Carter et al. 1988,

93 1998, 2010, Goričan et al. 2006, 2018, O’Dogherty et al. 2009). The results reveal that the

94 youngest ages are fairly homogenous along the entire Cache Creek belt, which provides some

95 clues regarding the accuracy of current tectonic models such as the Cache Creek Terrane

96 entrapment in its present form (Mihalynuk et al. 1994). Finally, the study provides some new

97 elements for stratigraphic comparison of the Cache Creek Terrane with other main oceanic units

98 of the Canadian Cordillera during the Jurassic (Cordey and Schiarizza 1993, Monger and Gibson

99 2019).

100

101

\section{Material and Methods}

103

104 The radiolarian assemblages presented in this paper are part of a large dataset of Devonian to

105 Jurassic radiolarian samples collected and studied in several terranes of the Canadian Cordillera

106 since the 1980s. Among them, the youngest Jurassic assemblages of the Cache Creek Terrane

107 were found at eight localities from southern British Columbia to southern Yukon (Fig. 2: J1,

108 Pavilion; J2, Alkali Lake; J3, Blackwater; J4, Pinchi Lake; J5, French Range; J6-J8, Teslin

109 Plateau). The geological setting and lithostratigraphy of these localities are described in detail in

110 former publications (J1: Mortimer 1987, Cordey et al. 1987, Cordey 1998; J2: Read 1993,

111 Cordey, unpub. data; J3: Cordey and Struik 1996, Orchard et al. 2001; J4: Orchard et al. 2001,

112 Struik et al. 2001; J5: Mihalynuk et al. 2004; J6-J8: Cordey et al. 1991).

113 The radiolarian faunas from the Cache Creek Terrane are usually poorly or moderately preserved

114 due to silica recrystallization as a result of diagenesis associated with $\mathrm{P} / \mathrm{T}$ conditions during 
115

116

117

118

119

120

121

122

123

tectonic emplacement and local magmatic intrusions. To maximize the quality of the

microfossils, the samples were selected with specific field detection techniques applied to pelagic strata from orogenic belts, using a strong hand lens and investigating specific microfacies such as argillaceous layers within chert beds (Cordey \& Krauss 1990, Cordey 1998). Radiolarians were then extracted by repetitive leaching of samples with low-concentration hydrofluoric acid (HF) and then hand-picked and mounted on aluminum stubs for SEM observation and taxonomical identifications (Tabletop SEM Phenom ProX, Laboratoire de Géologie de Lyon).

Although most radiolarian assemblages presented here are described in previous publications, new SEM images have been obtained for a selection of samples to improve the quality of previous illustrations and complement former studies with new taxa.

When microfossil assemblages are not well-preserved, radiolarians are usually identified at the genus level only ( $\mathrm{J} 1, \mathrm{~J} 2, \mathrm{~J} 5, \mathrm{~J} 7, \mathrm{~J} 8$; Table 1$)$. In this case, the age is established from overlapping ranges of genera (O’Dogherty et al. 2009). Other assemblages show a better state of preservation with radiolarians identified at the species level (J3, J4, J6), allowing correlations to more precise biozones (Carter et al. 1988, Cordey 1998, Whalen and Carter 2002, Goričan et al. 2006, Carter et al. 2010). A selection of biostratigraphically-significant radiolarians is presented in Figures 5 and 6. Radiolarian assemblages and ages are synthesized in Table 1.

\section{Results}

\section{New radiolarian assemblage from the type locality}

In southern British Columbia, the Cache Creek Terrane is divided into three belts (Figs. 3, 4) (Duffell and McTaggart 1952, Trettin 1980, Shannon 1981, Monger and McMillan 1984, Monger 1985, Mortimer 1987). The central belt is composed of massive limestone and marble of the 
140 Marble Canyon Formation where schwagerinid fusulinids of Late Permian age (Colania

141 assemblage) belong to a Tethyan faunal province and are cited as evidence that carbonate units of

142 the Cache Creek Terrane are far-travelled (Monger and Ross 1971; Monger et al. 1982; Danner

143 1985; Orchard et al. 2001). To the west of Marble Canyon, the western belt contains the youngest

144 strata of the type locality as shown by Early or Middle Jurassic radiolarians found in siliceous

145 argillites above Hambrook Creek (“R2”, Cordey et al. 1987, Cordey 1998).

146 With the aim of improving this previous radiolarian dating, this locality was resampled (NEO-R2,

147 Figs. 3, 4). A new radiolarian assemblage J1 (Table 1) is composed of the following taxa:

148 Archaeodictyomitra sp., Homoeoparonaella sp. cf. reciproqua Carter, Hsuum sp.,

149 Pseudocrucella? sp., Thurstonia sp., Trillus sp., Xiphostylus? sp., Triactoma sp., and Zartus sp..

150 The previous collection was dated as Pliensbachian-Bajocian based on the age range of Zartus

151 sp. (Cordey et al. 1987). In the new sample NEO-R2, the co-occurrence of Thurstonia sp., Trillus

152 sp. and Zartus sp. provides an age restricted to the Early Pliensbachian-Early Toarcian interval

153 (O’Dogherty et al. 2009). Although the preservation of the assemblage is poor, the specimens of

154 Thurstonia sp. display well-developed nodes at pore frame intersections (Fig. 5, no. 1), showing

155 affinities with Thurstonia specimens from the northern part of the Cache Creek Terrane (J6, Fig.

156 5, no. 3) as well as Thurstonia sp. B documented in Early Jurassic radiolarian assemblages from

157 the Bridge River and Hozameen terranes (Cordey 1998).

\section{Refined Jurassic radiolarian ages}

160 Southern British Columbia

161 An Early Jurassic radiolarian assemblage was found in gray-green radiolarian chert of the Riske

162 Creek Formation in the Alkali Lake map area (locality J2, Fig. 2) as a result of mapping and 163 sampling by Read (1993). Such as J1, it is located within the western belt of the terrane. This 164 assemblage is composed of Canutus sp., Lantus sp., Orbiculiformella sp., Parahsuum sp. and 
165

166

167

168

169

170

\section{1}

172

173

174

175

176

177

178

179

180

181

182

Praeconocaryomma sp. (Table 1). Originally dated as Sinemurian or Pliensbachian, its age is refined to the Early Pliensbachian-Early Toarcian interval (Table 1) based on co-occurrence of the genera Canutus sp. and Lantus sp.. (O’Dogherty et al. 2009). It is noteworthy that the age ranges of $\mathrm{J} 1$ and $\mathrm{J} 2$ assemblages are identical, although based on different radiolarian taxa.

\section{Central British Columbia}

Geological mapping of the Cache Creek Terrane in central British Columbia (Struik et al. 2007 and references therein) resulted in an important number of Paleozoic and Mesozoic radiolarian collections (Cordey and Struik 1996, Struik 1998, Orchard et al. 2001). The youngest radiolarian chert succession of this region is exposed along the Blackwater River in Punchaw Lake map area (J3, Fig. 2), $25 \mathrm{~km}$ to the south-southwest of the town of Prince George (Cordey and Struik 1996, Orchard et al. 2001, Struik et al. 2001). This succession is broadly continuous and contains Middle Triassic, Late Triassic, and Early Jurassic radiolarians. The youngest radiolarian assemblage found near the top of the section was initially dated as Pliensbachian (Cordey and Struik 1996, Orchard et al. 2001). Complementary chemical processing and new SEM images reveal an abundant and well-preserved assemblage (Table 1) composed of Atalantria sp., Beatricea? argescens Cordey, Bipedis japonicus Hori, Broctus sp., Canoptum rugosum Pessagno \& Poisson, Canoptum sp. cf. dixoni Pessagno \& Whalen, Charlottea sp., Katroma sp. cf. elongata Carter, Lantus sp. cf. praeobesus Carter, Laxtorum sp., Orbiculiformella? trispina s.1. (Yeh), Orbiculiformella sp., Palaeosaturnalis sp., Parahsuum simplum Yao, Parahsuum vizcainoense Whalen \& Carter, Praeconocaryomma sp. cf. sarahae Carter, Thurstonia sp. and Spumellaria gen. sp. indet. (Figs. 5, 6). This assemblage corresponds to the interval from the middle part of the Canutus tipperi - Katroma clara Zone to the base of the Gigi fustis - Lantus sixi Zone of Early Pliensbachian age (Carter et al. 2010). 
In the Fort-St-James area, the Tezzeron succession (originally called the Pinchi succession by

191 Struik et al. (1996) and Cordey and Struik (1996)) is exposed to the north of Stuart and Pinchi

192 lakes and bears some similarities with clastic assemblages from the upper part of the Cache Creek

193 Terrane in southern British Columbia (Shannon 1981, Monger 1985) and in Yukon (Cordey et al.

194 1991, Gordey and Stevens 1994). It is interpreted as belonging to the Cache Creek Terrane

195 (Bellefontaine et al. 1995, Struik et al. 1996, Orchard et al. 2001, Struik et al. 2001).

196 Within the Tezzeron succession, a limy siltstone unit located near the south end of Pinchi Lake

197 contains an Early Jurassic radiolarian assemblage (J4, Fig. 2, Table 1) previously reported by

198 Orchard et al. (2001) and Struik et al. (2001). It is composed of Emiluvia? sp. A (Carter et al.

199 1988), Hsuum lucidum Yeh (formerly interpreted as H. sp. cf. optimum Carter), Paronaella

200 grahamensis Carter, Praeconocaryomma decora gr. Yeh (formerly P. sp. A), and

201 Praeparvicingula tlellensis Carter (formerly Parvicingula sp. E, Carter et al. 1988). This

202 assemblage was originally assigned to the biozones 2 to 5 of Carter et al. (1988). It correlates

203 with the Elodium pessagnoi-Hexasaturnalis hexagonus Zone of Carter et al. (2010) of Middle-

204 Late Toarcian age. The corresponding sample, which is a limy siltstone, cannot be considered

205 part of "deep ocean" Cache Creek strata. It shows, however, that radiolarian pelagic input lasted

206 until the Toarcian, at least locally.

207

208 Northern British Columbia

209 In the French Range to the west of the Dease Lake area, a unit belonging to the Cache Creek

210 Terrane is composed of cherty argillites with local tuffaceous layers that contain Middle Triassic

211 and Early Jurassic radiolarians (Mihalynuk et al. 2004). This succession is correlative to the rocks

212 on the Teslin Plateau, $200 \mathrm{~km}$ to the north (Cordey et al. 1991). One Early Jurassic radiolarian

213 assemblage (J5, Fig. 2, Table 1) was extracted from a black cherty argillite exposure located 2.5

$214 \mathrm{~km}$ to the north of Slate Creek. It is from blueschists, and therefore places a maximum age limit 
215

216

217

218

219

220

221

222

223

224

225

226 Yukon

227

228

229

230

231

232

233

234

235

236

237

238

239

on blueschist mineral formation ((Mihalynuk et al. 2004). The assemblage is composed of

Parahsuum izeense (Pessagno \& Whalen) (formerly Canutus izeensis Pessagno \& Whalen),

Orbiculiformella? trispina s.1. (Yeh) (formerly Orbiculiforma silicatilis Cordey),

Praeconocaryomma sp. cf. sarahae Carter (formerly P. aff. media Pessagno \& Poisson),

Praeconocaryomma sp., and Thurstonia sp. (Table 1). Initially, the radiolarian assemblage was

dated as Pliensbachian-Toarcian (Mihalynuk et al. 2004). The age is revised to the

Pliensbachian-Early Toarcian based on the occurrence of Parahsuum izeense Pessagno \&

Whalen and the refined range of Thurstonia (Table 1). The presence of Praeconocaryomma sp.

cf. sarahae Carter suggests that this assemblage could be restricted to the Pliensbachian (Carter et

al. 2010), but this cannot be confirmed due to the incomplete nature of the specimen.

An assemblage composed of radiolarian cherts and fine-grained clastic rocks is exposed on the Teslin Plateau, $\sim 20 \mathrm{~km}$ to the north of the British Columbia-Yukon border (Gordey 1991). This succession has previously been called the Lewes River assemblage (Wheeler et al. 1991, Gordey 1991) or Teenah Lake assemblage (Jackson 1992), and is equivalent in part to the Kedahda Formation of Monger (1975). Several localities with Middle Triassic, Late Triassic, and Early Jurassic radiolarian assemblages were discovered along a five-kilometre-long ridge north of Mount Bryde and Sterlin Lake (Gordey 1991, Cordey et al. 1991). The ridge consists of successive outcrops and isolated sections of stacked radiolarian chert, argillite and graywacke previously described and discussed in detail (Cordey et al. 1991).

The first Early Jurassic radiolarian assemblage J6 (Fig. 2, Table 1) is from siliceous argillite interbedded with graywacke that contain Bipedis sp., Broctus sp., Canoptum anulatum Pessagno \& Poisson, Canoptum sp., Hagiastrum majusculum Whalen \& Carter (formerly called H. sp. A, Cordey 1998), Homoeoparonaella sp., Lantus sixi Yeh, Napora cerromesaensis Pessagno, 
240 Whalen \& Yeh, Pantanellium cumshewaense Pessagno \& Blome, Parahsuum izeense (Pessagno

241 \& Whalen) (formerly described as Canutus giganteus Pessagno \& Whalen), Praeconocaryomma?

242 sp. cf. yakounensis Carter (formerly interpreted as Praeconocaryomma. sp. aff. P. sp. B Yeh),

243 Thurstonia sp., and Wrangellium sp.. This assemblage was originally dated as

244 Pliensbachian-Early Toarcian (Table 1). It is now correlated with the base of the Gigi fustis -

245 Lantus sixi Zone to the middle part of the Eucyrtidiellum nagaiae-Praeparvicingula tlellensis

246 Zone (Unitary associations UA 12-22) (Carter et al. 2010), establishing a late Early Pliensbachian

247 to Late Pliensbachian age.

248 The second youngest Early Jurassic sample on the Teslin Plateau (J7, Fig. 2, Table 1) is from a

249 radiolarian chert succession located $4 \mathrm{~km}$ to the south of J6 (Cordey et al. 1991). It was

250 previously dated as Sinemurian-Toarcian (Cordey et al. 1991). It is composed of Beatricea?

251 argescens Cordey, Canoptum sp. cf. anulatum Pessagno \& Poisson (previously interpreted as

252 Wrangellium sp. cf. thurstonense Pessagno \& Whalen), Canoptum sp., Praeconocaryomma sp.

253 cf. immodica Pessagno \& Poisson, and Wrangellium sp. (Table 1). The age is here refined to the

254 Late Sinemurian-Late Pliensbachian interval based on the co-occurrence of Beatricea sp. and

255 Wrangellium sp..

256 The third sample (J8, Fig. 2, Table 1) is part of the same radiolarian chert succession and location

257 as $\mathrm{J} 7$. The radiolarian assemblage is composed of Beatricea? argescens Cordey, Bipedis sp.,

258 Canoptum sp. cf. dixoni Pessagno \& Whalen, Gorgansium sp., Pantanellium sp., Parahsuum sp.,

259 Praeconocaryomma sp., and Wrangellium sp.. It was previously dated as Sinemurian-Toarcian

260 (Cordey et al. 1991). It is here refined to the Late Sinemurian-Late Pliensbachian interval, based

261 on the co-occurrence and refined ranges of Beatricea sp., Bipedis sp. and Wrangellium sp. (Table

$2621)$ 


\section{Discussion}

\section{Homogeneity of youngest Cache Creek ages}

268 Revised Jurassic radiolarian ages reveal that the youngest Cache Creek ages are fairly

269 homogenous along the entire Canadian Cordillera (Fig. 7). These ages are comprised within the

270 Late Sinemurian-Late Toarcian interval ( 195-174 Ma, Cohen et al. 2013). The siliceous rocks

271 (radiolarian chert and siliceous argillite) are restricted to the Late Sinemurian-Early Toarcian

272 interval ( 195-180 Ma), including error margins. The most precise age determinations from

273 central British Columbia and Yukon (Fig. 7) indicate that the youngest true radiolarian cherts (=

274 devoid of clastic intercalations) are Pliensbachian in age (J3), and the youngest siliceous argillites

275 may also be Pliensbachian in age, possibly reaching the Early Toarcian (J1, J5, J6). The youngest

276 Jurassic age obtained on a limy siltstone in the Tezzeron succession (J4) suggests that radiolarian

277 pelagic input possibly lasted until the Middle or Late Toarcian in central British Columbia,

278 although chert sedimentation might have ceased. To date, no pelagic sedimentary strata of Middle

279 Jurassic age have been found in the Cache Creek Terrane.

281 Cache Creek Terrane and overlap assemblages

282 Some of the youngest Cache Creek strata have locally been interpreted as overlap assemblages,

283 for instance the chert-argillite-graywacke successions exposed on the Teslin Plateau (Lewes

284 River assemblage, Wheeler et al. 1991, Gordey 1991; Teenah Lake assemblage, Jackson 1992).

285 More recently, all post-Middle Triassic sequences were proposed to represent overlap

286 assemblages on top of already assembled terranes including the Paleozoic units of the Cache

287 Creek Terrane (Zagorevski et al. 2017).

288 The notion of an "overlap assemblage" implies that marine sedimentation ceased prior to the 289 deposition of clastic sediments on top of exhumed oceanic units. Regarding the Cache Creek 
290 Terrane, this view is not consistent with the occurrence of radiolarian chert sedimentation as

291 young as Pliensbachian or of Middle Jurassic blueschists with in part Early Jurassic sedimentary

292 protoliths (Mihalynuk et al. 2004), which demonstrate that deep ocean sedimentation persisted

293 between Stikinia and Quesnellia until the end of the Early Jurassic. In central British Columbia

294 (Blackwater; Figs. 7, 8), a Triassic-Early Jurassic chert succession also suggests that Cache

295 Creek marine sedimentation was continuous prior to the closure of the basin. However, pelagic

296 and clastic regimes are interrelated: in the northern part of the Cache Creek Terrane, the argillites

297 and graywackes are locally intercalated with Late Triassic radiolarian cherts (Cordey et al. 1991).

298 More recently, a Hettangian age (199.5 $\pm 2.0 \mathrm{Ma})$ was obtained on detrital zircons from a Cache

299 Creek graywacke east of Carcross (Colpron et al. 2015) and interpreted as a probable distal

300 equivalent of the Richtofen Formation (Laberge Group), showing a probable link between the

301 Cache Creek Terrane and the Whitehorse trough as early as the end of the Triassic or the

302 beginning of the Jurassic. The input of clastic sediments within Cache Creek pelagic strata may

303 be a result of the geometry of the terrane at this time, flanking the Yukon-Tanana Terrane to the

304 north during the counterclockwise rotation of Stikinia ("isolation stage" of Mihalynuk et al. 1994;

305 Colpron et al. 2015). These transitional regimes evolved towards a narrowing Cache Creek basin

306 incorporating thicker and coarser siliciclastic sediments associated with tectonic convergence in

307 the form of synorogenic piggyback basins (Colpron et al. 2015, Bickerton et al. 2020).

308 Numerous examples of pelagic to clastic successions are found in other segments of the circum-

309 Pacific ranges such as in Japan and Siberia where the Permian-Jurassic oceanic terranes display

310 Jurassic intercalations of radiolarian chert, siliceous argillite and sandstone interpreted as ocean

311 environments within the depositional influence of one continental margin or flanking sources

312 (Isozaki et al. 1990, Matsuoka et al. 1996). In general, the intercalations and lateral facies

313 changes between pelagic and clastic rocks make it difficult to delineate a clear boundary where

314 oceanic terrane sedimentation ends and where clastic assemblages begin. This is true for the 
315 Cache Creek Terrane in the Yukon, but also in southern British Columbia (Mortimer 1987,

316 Cordey et al. 1987). The composite nature of Cordilleran oceanic terranes, i.e. the likelihood for

317 these terranes to be the end-result of juxtaposed basinal entities, has previously been suggested

318 for the Bridge River Terrane (Cordey and Schiarizza 1993, Cordey 1998) and the Cache Creek

319 Terrane (Golding 2018) but these hypotheses do not challenge the interpretation that these

320 terranes were dominantly oceanic until the final stages of convergence.

322 Cache Creek closure: fast entrapment?

323 Several models have been proposed for the tectonic mechanism of Cache Creek Ocean closure

324 (see Golding 2018 for a recent review). The consensus model of Cache Creek "entrapment" from

325 Nelson and Mihalynuk (1993) and Mihalynuk et al. (1994) proposes that the terrane became

326 enclosed between the Stikinia and Quesnellia terranes leading to Cache Creek oceanic crust being

327 subducted during an oroclinal bending event, with a progressive "scissor-like" closure from north

328 to south, and the Yukon-Tanana Terrane acting as the hinge. In this scenario, the Whitehorse

329 trough is considered a northern precursor to the Bowser Basin (Ricketts et al. 1992, Evenchick et

330 al. 2010) accompanying the final stages of convergence and closure (Colpron et al. 2015).

331 The entrapment model implies a diachronous closure of the Cache Creek Ocean, with the

332 youngest oceanic sedimentary rocks progressively younging to the south (basin isolation

333 followed by closure, Mihalynuk et al. 1994). The updated radiolarian ages suggest instead a

334 relative synchronicity in the cessation of pelagic sedimentation along the entire Cache Creek

335 Terrane. While Yukon hemipelagic rocks (J6) are Pliensbachian in age, a similar age

336 (Pliensbachian-Early Toarcian) is obtained on siliceous argillites $1200 \mathrm{~km}$ to the south in the

337 type locality (J1). Additionally, radiolarian cherts from central British Columbia (J3) and Yukon

338 (J8) could have a common Pliensbachian age, even though they are $\sim 1000 \mathrm{~km}$ apart.

339 One could argue that the speed and geometry of the counterclockwise oroclinal bending of 
340 Stikinia towards Quesnellia are not precisely known. One way to reconcile the entrapment model

341 with the relative synchronicity of the youngest Cache Creek oceanic strata is through very rapid 342 tectonic rotation. In northern British Columbia, Mihalynuk et al. (1994, 2004) assessed that the

343 final closure of the Cache Creek Terrane in the north occurred before $171 \mathrm{Ma}$ (late Aalenian or 344 early Bajocian, Cohen et al. 2013), the age of the post-kinematic Fourth of July batholith that 345 intrudes deformed Cache Creek units in the Atlin Lake area (Mihalynuk et al. 1992). The 346 minimum age of Cache Creek extrusion in the French Range was constrained to $174.5-172 \mathrm{Ma}$ 347 (latest Toarcian or Aalenian, Cohen et al. 2013), using the interval between the youngest 348 blueschists and the oldest intrusions (Mihalynuk et al. 2004). In the south, the Cache Creek 349 Terrane was thrust eastward over Quesnellia in the Late Jurassic ( $\leq 160 \mathrm{Ma})$ (Travers 1978). The most precise ages of the youngest Cache Creek Terrane strata are Pliensbachian and found in 351 central British Columbia (J3) and Yukon (J6). The Early Pliensbachian chert J3 (Figs. 7, 8) found 352 at the top of a Triassic-Early Jurassic succession along the Blackwater River in central British 353 Columbia is a good time proxy for the age of the youngest and still truly oceanic Cache Creek 354 sedimentation at the center of the Cache Creek belt, suggesting that the youngest sustained 355 hemipelagic sedimentation in southern British Columbia could be slightly younger, possibly Late 356 Pliensbachian or Early Toarcian, predating the final closure of the Cache Creek Ocean. In this 357 case, the final phase of the counterclockwise rotation of Stikinia must have occurred within 8 358 m.y. (the interval between late Early Pliensbachian and Early Toarcian, 188-180 Ma, Cohen et 359 al. 2013).

361 Comparison between youngest Cache Creek and Bridge River ages

362 Since the 1980s, geological and paleontological studies have established that the oceanic strata of 363 the Cache Creek and the Bridge River terranes (Fig. 1) share fairly similar Carboniferous-Jurassic 364 stratigraphic ages (Cordey et al. 1987, Mihalynuk et al. 1994, Monger 2014). The Hozameen 
365 Terrane exposed in southern British Columbia and northern Washington (Fig. 1) is considered as 366 a southern continuation of the Bridge River Terrane (Monger 1985).

367 Early Jurassic radiolarian assemblages found in the Cache Creek Terrane are also present in the 368 Bridge River and Hozameen terranes which contain Pliensbachian and Toarcian radiolarian 369 cherts (Cordey and Schiarizza 1993, Cordey 1998). However, the cherts of the Bridge River 370 Terrane document a pelagic sedimentation that lasted significantly longer: the youngest 371 radiolarian assemblages are from the Noaxe Creek area (Cordey and Schiarizza 1993, Cordey 372 1998) where six localities are Middle Jurassic (Aalenian-Bajocian, Early-Middle Bathonian, 373 Late Bathonian-Middle Callovian, Late Bathonian-Late Callovian), and one locality is Middle 374 or Late Jurassic (Late Callovian-?Middle Oxfordian) based on biozonations for the Middle-Late 375 Jurassic (Baumgartner et al. 1995, Matsuoka 1995, Goričan et al. 2018). This Bridge River 376 radiolarian chert succession probably grades into Late Jurassic and earliest Cretaceous clastic 377 rocks of the Tyaughton-Methow basin (Mahoney and Journeay 1993, Cordey 1996, Monger 378 2014, Monger and Gibson 2019).

379 It is hypothesized here that the youngest radiolarian chert of the Cache Creek Terrane is Early 380 Pliensbachian in age ( 191-187 Ma, Cohen et al. 2013) based on the well-constrained 381 assemblage at the Blackwater section in central British Columbia (J3, Figs. 7-8). In the Bridge 382 River Terrane, the youngest age for a radiolarian chert is within the "Late Callovian - Middle 383 Oxfordian" interval ( 165-160 Ma, Cohen et al. 2013). These ages imply that the Cache Creek 384 Terrane oceanic sedimentation had ceased since 22 to $31 \mathrm{~m} . \mathrm{y}$. (minimum and maximum possible 385 durations due to the error margins of biostratigraphic data, corresponding to "Late 386 Pliensbachian-Late Callovian" and "Early Pliensbachian-Middle Oxfordian" intervals, 387 respectively) while the Bridge River Ocean was still recording pelagic sedimentation in the 388 Middle Jurassic and possibly the early Late Jurassic. 
The question whether the Cache Creek and Bridge River terranes mark two distinct sutures or are the remnants of a single oceanic domain has long been debated (Monger et al. 1972, Coney et al. 1980, Monger et al. 1982, Monger 1985, Cordey 1986, Cordey et al. 1987, Monger et al. 1994, 394 Nokleberg et al. 2000, Dickinson 2004, Johnston and Borel 2006, Gehrels et al. 2009). This issue has been revived by Sigloch and Mihalynuk $(2013,2017)$ who combined high-resolution tomography, plate reconstructions and the concept of vertical slab walls. Their analysis of the North American Cordillera implies that a cryptic suture zone existed between the Insular and Intermontane superterranes. In this model, the Bridge River Terrane corresponds to the land remnant of an intraoceanic domain identified in the subducted Mezcalera slab wall (named from the Mezcalera oceanic plate hypothesized in Mexico by Dickinson and Lawton 2001). However, some authors question the accuracy of this "two-sutures" model which also implies a west-dipping subduction zone inboard of Wrangellia (see the recent discussion by Pavlis et al. 2019). Monger (2014) and Monger and Brown (2016) have proposed instead that the Bridge River and Hozameen terranes are the southern continuation of the Cache Creek Terrane, prior to dextral displacements of $\sim 115 \mathrm{~km}$ on the latest Cretaceous-Paleocene Yalakom Fault (Umhoefer and Schiarizza 1996) and $140 \mathrm{~km}$ of Eocene movement on the Fraser-Straight Fault (Monger and Brown 2016). The age discrepancy between the two terranes is interpreted by implying that

408 the Bridge River Terrane faced open ocean to the west until it was trapped in the Early

409 Cretaceous $(\leq 130 \mathrm{Ma})$ behind the arc rocks in the southwestern Coast Mountains, whereas in 410 northern British Columbia, the Cache Creek Terrane was thrust southwestward over Stikinia in 411 the earliest Middle Jurassic ( 174 Ma) (Mihalynuk et al. 2004), and in southern British Columbia 412 was thrust eastward over Quesnellia probably in the Late Jurassic ( $\leq 160 \mathrm{Ma})$ (Travers 1978).

413 The likelihood of differentiating the two terranes based on provincial radiolarian signatures has 414 been discussed by Cordey (1998) and Orchard et al. (2001) and present some limitations. Some 
415 elements of correlation with Tethyan assemblages may be found in older Paleozoic and Triassic

416 assemblages of the Cache Creek Terrane (Cordey 1998, Orchard et al. 2001), but also in the

417 Bridge River Terrane (Cordey and Schiarizza 1993, Cordey 1996, Cordey 1998). During the

418 Jurassic, one can only demonstrate that the Bridge River Terrane has a longer record of chert

419 sedimentation than the Cache Creek Terrane.

\section{Conclusions}

424 So far as known, all the youngest radiolarian assemblages of the Cache Creek Terrane are Early

425 Jurassic in age, including in the type locality in southern British Columbia. All refined ages of the

426 youngest radiolarian cherts and siliceous argillites are within the Late Sinemurian-Early Toarcian

427 interval $(\sim 195-180 \mathrm{Ma})$ with a possible Pliensbachian common age ( 191-183 Ma). Well-dated

428 Early Pliensbachian radiolarian cherts are exposed in the central part of the terrane and may

429 correspond to the youngest pelagic strata. These results suggest that Cache Creek deep pelagic

430 "true chert" sedimentation ceased fairly synchronously along the entire belt, probably during the

431 Pliensbachian, followed by hemipelagic sedimentation in the Pliensbachian and/or the Toarcian,

432 predating the final closure of the basin that occurred by tectonic thrusting of Cache Creek units

433 over Stikinia and Quesnellia in the Middle and Late Jurassic.

434 These results should lead to re-evaluating the tectonic mechanism of the Cache Creek entrapment

435 model in its present form, either in speed or geometry. In addition, the study shows that pelagic

436 sedimentation ceased 22 to 31 m.y. earlier in the Cache Creek Terrane than in the Bridge River

437 Terrane, confirming the stratigraphic discrepancy between the two terranes during the Jurassic.

438 These refined chronological data now need to be more precisely taken into account by the current

439 tectonic models which integrate the two terranes and the suture(s) they represent at the core of the 
440 discussion.

\section{Acknowledgements}

This study results from a long collaboration with regional geologists and paleontologists who

446 investigated the Cache Creek Terrane: J. Monger, M. Orchard, P. Read, N. Mortimer, H.

447 Gabrielse, S. Gordey, B. Struik, M. Mihalynuk, J. English, C. Floriet, H. Sano, J. Jackson, S.

448 Johnston, P. Schiarizza, and A. Zagorevski. Former fieldwork was supported by the Geological 449 Survey of Canada (Vancouver) and the British Columbia Geological Survey Branch (Victoria).

450 Laboratory facilities were provided by the Laboratoire de Géologie de Lyon (Centre National de 451 la Recherche Scientifique CNRS - Unité Mixte de Recherche UMR5276). Reviewers S. Goričan 452 and J. Nelson as well as Editor A. Polat and Associate Editor B. Pratt provided insightful 453 comments which significantly improved the first version of the manuscript.

\section{References}

Baumgartner, P.O., Bartolini, A., Carter, E.S., Conti, M., Cortese, G., Danelian, T., De Wever, P., 459 Dumitrica, P., Dumitrica-Jud, R., Goričan, Š., Guex, J., Hull, D.M., Kito, N., Marcucci, M., 460 Matsuoka, A., Murchey, B., O'Dogherty, L., Savary, J., Vishnevskaya, V., Widz, D., and Yao, A. 461 1995. Middle Jurassic to Early Cretaceous radiolarian biochronology of Tethys based on Unitary 462 Associations. In Middle Jurassic to Lower Cretaceous Radiolaria of Tethys: Occurrences, 463 Systematics, Biochronology. Edited by P.O. Baumgartner, L. O'Dogherty, Š. Goričan, E. 464 Urquhart, A. Pillevuit and P. De Wever. Mémoires de Géologie (Lausanne), Vol. 23, pp. 1013- 
1038.

467 Bellefontaine, K.A., Legun, A., Massey, N., and Desjardins, P. 1995. Digital Geological

468 Compilation of Northeast B.C. Southern Half (NTS 83D, E, 93F, G, H, I, J, K, N, O, P). British

469 Columbia Ministry of Energy Mines and Petroleum Resources, Open File 1995-24.

470

471 Beyers, J.M., and Orchard, M.J. 1989. Permian-Triassic boundary beds in the Cache Creek

472 Group, Marble Range, near Jesmond, British Columbia. In Current Research, Geological Survey

473 of Canada, Paper 89-1E, pp. 127-132. doi.org/10.4095/127466

Beyers, J.M., and Orchard, M.J. 1991. Upper Permian and Triassic conodont faunas from the

type area of the Cache Creek Complex, south-central British Columbia, Canada. In Ordovician to

477 Triassic conodont paleontology of the Canadian Cordillera. Edited by M.J. Orchard and A.D.

478 McCracken. Geological Survey of Canada, Bulletin 417, pp. 269-279. doi.org/10.4095/132441

479

Bickerton, L., Colpron, M., Gibson, H. D., Thorkelson, D., and Crowley, J. L. 2020. The northern termination of the Cache Creek terrane in Yukon: Middle Triassic arc activity and Jurassic-

Cretaceous structural imbrication. Canadian Journal of Earth Sciences, 57: 227-248. doi.org/10.1139/cjes-2018-0262

Carter, E.S., Cameron, B.E.B., and Smith, P.L. 1988. Lower and Middle Jurassic radiolarian biostratigraphy and systematic paleontology, Queen Charlotte Islands, British Columbia.

487 Geological Survey of Canada, Bulletin 386. doi.org/10.4095/126315

489 Carter, E.S., Whalen, P.A., and Guex, J. 1998. Biochronology and paleontology of Lower 
490 Jurassic (Hettangian and Sinemurian) radiolarians, Queen Charlotte Islands, British Columbia.

491 Geological Survey of Canada, Bulletin 496. doi.org/10.4095/209778

492

493 Carter, E.S., Goričan, Š., Guex, J., O’Dogherty, L., De Wever, P., Dumitrica, P., Hori, R.S., 494 Matsuoka, A., and Whalen, P. 2010. Global radiolarian zonation for the Pliensbachian, Toarcian 495 and Aalenian. Palaeogeography, Palaeoclimatology, Palaeoecology, 297: 401-419.

496 doi.org/10.3986/9789612545192

497

498 Cohen, K.M., Finney, S.C., Gibbard, P.L., and Fan, J.-X. 2013 (updated 2020). The ICS

499 International Chronostratigraphic Chart. Episodes, 36: 199-204. Available from

500 http://www.stratigraphy.org/index.php/ics-chart-timescale

501

502 Colpron, M., Crowley, J.L., Gehrels, G.E., Long, D.G.F., Murphy, D.C., Beranek, L.P., and 503 Bickerton, L. 2015. Birth of the northern Cordilleran orogen, as recorded by detrital zircons in 504 Jurassic synorogenic strata and regional exhumation in Yukon. Lithosphere, 7: 541-562. 505 doi:10.1130/L451.1.

506

507 Coney, P.J., Jones, D.L., and Monger, J.W.H. 1980. Cordilleran suspect terranes. Nature, 288 :

508 329-333. doi.org/10.1038/288329a0

509

510 Cordey, F. 1986. Radiolarian ages from the Cache Creek and Bridge River complexes and from 511 chert pebbles in Cretaceous conglomerates, British Columbia. Geological Survey of Canada 512 Paper 86-1A, pp. 595-602. doi.org/10.4095/120430

514 Cordey, F. 1996. Radiolarian chert terranes of the Canadian Cordillera: the Bridge River terrane 
515 and faunal comparison with East Asia. In Mesozoic radiolarians and radiolarian-bearing 516 sequences in the Circum-Pacific regions: A report of the symposium 'Radiolarians and Orogenic

517 Belts'. Edited by A. Matsuoka, Y. Aita, Munasri, K. Wakita, G. Shen, H. Ujiié, K. Sashida, V.S.

518 Vishnevskaya, N.Y. Bragin and F. Cordey. Island Arc, 5: 209-210. doi.org/10.1111/j.1440-

$519 \quad$ 1738.1996.tb00026.x

520

521 Cordey, F. 1998. Radiolaires des complexes d'accrétion cordillérains. Geological Survey of

522 Canada, Bulletin 509. doi.org/10.4095/209945

523

524 Cordey, F., and Krauss, P. 1990. A field technique for identifying and dating Radiolaria applied 525 to British Columbia and Yukon. In Current Research, part E. Geological Survey of Canada, Paper 526 90-1E, pp. 127-129. doi.org/10.4095/131378

528 Cordey, F., and Schiarizza, P. 1993. Long-lived Panthalassic remnant: the Bridge River 529 accretionary complex, Canadian Cordillera. Geology, 21: 263-266. doi.org/10.1130/0091$530 \quad$ 7613(1993)021<0263:LLPRTB>2.3.CO;2.

532 Cordey, F., and Struik, L.C. 1996. Radiolarian biostratigraphy and implications: Cache Creek 533 Group of Fort Fraser and Prince George map areas, central British Columbia. In Current 534 Research 1996-E. Geological Survey of Canada, pp. 7-18. doi.org/10.4095/207868

536 Cordey, F., Mortimer, N., De Wever, P., and Monger, J.W.H. 1987. Significance of Jurassic 537 radiolarians from the Cache Creek Terrane, southern British Columbia. Geology, 15: 1151-1154. 538 doi.org/10.1130/0091-7613(1987)15\%3C1151:sojrft\%3E2.0.co;2 
540 Cordey, F., Gordey, S.P., and Orchard, M.J. 1991. New biostratigraphic data for the northern

541 Cache Creek Terrane, Teslin map area, southern Yukon. In Current Research, Part E. Geological

542 Survey of Canada, Paper 91-1E, pp. 67-76. doi.org/10.4095/132629

543

544 Danner, W.R. 1985. Tethyan exotic terrane, southwestern British Columbia. In Field Trip No. 13, 545 Meetings of the Geological Society of America, Cordilleran Section, Vancouver, B.C.

547 Dickinson, W.R. 2004. Evolution of the North American Cordillera: Annual Review of Earth and 548 Planetary Sciences, 32: 13-45. doi:10.1146/annurev.earth.32.101802.120257.

Dickinson, W.R., and Lawton, T.F. 2001. Carboniferous to Cretaceous assembly and 551 fragmentation of Mexico. Geological Society of America Bulletin, 113: 1142-1160.

552 doi.org/10.1130/0016-7606(2001)113\%3C1142:ctcaaf\%3E2.0.co;2

554 Duffell, S., and McTaggart, K.C. 1952. Ashcroft map-area, British Columbia. Geological Survey 555 of Canada, Memoir 262. doi.org/10.4095/101598

557 Evenchick, C.A., Poulton, T.P., and McNicoll, V.J. 2010. Nature and significance of the 558 diachronous contact between the Hazelton and Bowser Lake groups (Jurassic), north-central 559 British Columbia. Bulletin of Canadian Petroleum Geology, 58: 235-267.

560 doi:10.2113/gscpgbull.58.3.235.

561

562 Gehrels, G., Rusmore, M., Woodsworth, G., Crawford, M., Andronicos, A., Hollister, L., 563 Patchett, P., Ducca, M., Butler, R., Klepeis, K., Davidson, C., Friedman, R., Haggart, J., 564 Mahoney, B., Crawford, W., Pearson, D., and Girardi, J. 2009. U-Th-Pb geochronology of the 
565 Coast Mountains batholith in north-coastal British Columbia: constraints of age and tectonic 566 evolution. Geological Society of America Bulletin, 1201: 1340-1361. doi.org/10.1130/B26404.1.

568 Golding, M. 2018. Heterogeneity of conodont faunas in the Cache Creek Terrane, Canada; 569 significance for tectonic reconstructions of the North American Cordillera. Palaeogeography, 570 Palaeoclimatology, Palaeoecology, 506: 208-216. doi.org/10.1016/j.palaeo.2018.06.038

572 Gordey, S.P. 1991. Teslin map area, a new geological mapping project in southern Yukon. In

573 Current research, Part A. Geological Survey of Canada, Paper 91-1A, pp. 171-178.

574 doi.org/10.4095/132511

575

576 Gordey, S.P., and Stevens, R.A. 1994. Tectonic framework of the Teslin region, southern Yukon 577 Territory. In Current research, part A. Geological Survey of Canada, Paper 94-A, pp. 11-18. 578 doi.org/10.4095/193617

579

580 Goričan, Š., Carter, E.S., Dumitrica, P., Whalen, P.A., Hori, R.S., De Wever, P., O’Dogherty, L., 581 Matsuoka, A., and Guex, J. 2006. Catalogue and systematics of Pliensbachian, Toarcian and 582 Aalenian radiolarian genera and species. Založba ZRC, Ljubljana.

583 doi.org/10.3986/9789612545192

584

585 Goričan, Š., O’Dogherty, L., Baumgartner, P.O., Carter E.S., and Matsuoka, A. 2018. Mesozoic 586 radiolarian biochronology - current status and future directions. Revue de micropaléontologie, 587 61: 165-189. doi.org/10.1016/j.revmic.2018.08.001

589 Isozaki, Y., Maruyama, S., and Furuoka, F. 1990. Accreted oceanic materials in Japan. 
590 Tectonophysics, 181: 179-205. doi.org/10.1016/0040-1951(90)90016-2

591

592 Jackson, J.L. 1992. Tectonic analysis of the Nisling, northern Stikine and northern Cache Creek

593 terranes, Yukon and British Columbia. Ph.D. thesis, University of Arizona, Tucson.

594

595 Johnston, S.T., and Borel, G.D. 2006. The odyssey of the Cache Creek terrane, Canadian

596 Cordillera: Implications for accretionary orogens, tectonic setting of Panthalassa, the Pacific

597 superwell, and break-up of Pangea. Earth and Planetary Science Letters, 253: 415-28.

598 doi:10.1016/j.epsl.2006.11.002

599

600 Matsuoka, A. 1995. Jurassic and Lower Cretaceous radiolarian zonation in Japan and in the

601 western Pacific. The Island Arc, 4: 140-153. doi.org/10.1111/j.1440-1738.1995.tb00138.x

602

603 Matsuoka, A., Aita, Y., Munasri, Wakita, K., Shen, G., Ujiii, H., Sashida, K., Vishnevskaia, V.,

604 Bragin, N., and Cordey, F. 1996. Mesozoic radiolarians and radiolarian-bearing sequences in the

605 circum-Pacific regions: A report of the symposium-'Radiolarians and Orogenic Belts'. The Island

606 Arc, 5: 203-213. doi.org/10.1111/j.1440-1738.1996.tb00026.x

607

608 Mihalynuk, M.G., Smith, M.T. Gabites, J.E., Runkle, D., and Lefebure, D. 1992. Age of

609 emplacement and basement character of the Cache Creek terrane constrained by new

610 geochemical data. Canadian Journal of Earth Sciences, 29: 2463-2477. doi.org/10.1139/e92-193 
612 Mihalynuk, M.G., Nelson, J.A., and Diakow, L.J. 1994. Cache Creek terrane entrapment:

613 oroclinal paradox within the Canadian Cordillera. Tectonics, 13: 575-595.

614 doi.org/10.1029/93tc03492

615

616 Mihalynuk, M.G., Erdmer, P., Ghent, E.D., Cordey, F., Archibald, D.A., Friedman, R.M., and

617 Johannson, G.G. 2004. Coherent French Range blueschist: Subduction to exhumation in $<2.5$

618 m.y.? Geological Society of America Bulletin, 116: 910-922. doi.org/10.1130/b25393.1

619

620 Monger, J.W.H. 1975. Upper Paleozoic rocks of the Atlin Terrane, northwestern B.C. and south-

621 central Yukon. Geological Survey of Canada, Paper 74-47, pp 1-63. doi.org/10.4095/102554

622

623 Monger, J.W.H. 1981. Geology of parts of western Ashcroft map area, southwestern British

624 Columbia. In Current Research, Part A. Geological Survey of Canada, Paper 81-1A, pp. 185-

625 189. doi.org/10.4095/109627

626

627 Monger, J.W.H. 1985. Structural evolution of the southwestern Intermontane belt, Ashcroft and

628 Hope map areas, British Columbia. In Current Research, Part A. Geological Survey of Canada, 629 Paper 85-1A, pp. 349-358. doi.org/10.4095/120183

630

631 Monger, J.W.H. 2014. Logan Medallist 1. Seeking the Suture: The Coast-Cascade Conundrum.

632 Geoscience Canada, 41: 379-398. doi.org/10.12789/geocanj.2014.41.058

634 Monger, J.W.H., and Brown, E.H. 2016. Tectonic evolution of the southern Coast-Cascade

635 Orogen, northwestern Washington and southwestern British Columbia. In Chapter 10, The

636 Geology of Washington and Beyond: From Laurentia to Cascadia. Edited by E.S. Cheney, 
637 University of Washington Press, pp. 101-130.

638

639 Monger, J.W.H., and Gibson, H.D. 2019. Mesozoic-Cenozoic deformation in the Canadian

640 Cordillera: The record of a "Continental Bulldozer”? Tectonophysics, 757: 153-169.

641 doi.org/10.1016/j.tecto.2018.12.023

642

643 Monger, J.W.H., and McMillan, W.J. 1984. Bedrock geology of Ashcroft (92 I) map area.

644 Geological Survey of Canada, Open-File Report 980. doi.org/10.4095/129860

645

646 Monger, J.W.H., and Ross, C.A. 1971. Distribution of fusulinaceans in the western Canadian

647 Cordillera. Canadian Journal of Earth Sciences, 8: 259-278. doi.org/10.1139/e71-026

648

649 Monger, J.W.H., Souther, J.G., and Gabrielse, H. 1972. Evolution of the Canadian Cordillera; a

650 plate tectonic model. American Journal of Science, 272: 577-602. doi.org/10.2475/ajs.272.7.577 651

652 Monger, J.W.H., Price, R.A., and Tempelman-Kluit, D.J. 1982. Tectonic accretion and the origin 653 of the two major metamorphic and plutonic welts in the Canadian Cordillera. Geology, 10: 70654 75. doi.org/10.1130/0091-7613(1982)10<70:TAATOO >2.0.CO;2.

655

656 Monger, J.W.H., Van der Heyden, P., Journeay, J.M., Evenchick, C.A., and Mahoney, J.B. 1994.

657 Jurassic-Cretaceous basins along the Canadian Coast belt: Their bearing on pre-mid-Cretaceous

658 sinistral displacements. Geology, 22: 175-178. doi.org/10.1130/0091-

659 7613(1994)022<0175:JCBATC $>2.3 . \mathrm{CO} ; 2$.

660

661 Mortimer, N. 1987. The Nicola Group: Late Triassic and Early Jurassic subduction-related 
662 volcanism in British Columbia. Canadian Journal of Earth Sciences, 24: 2521-2536.

663 doi.org/10.1139/e87-236

664

665 Nelson, J.L., and Mihalynuk, M.G. 1993. Cache Creek Ocean: closure or enclosure? Geology,

666 21: 173-176. doi.org/10.1130/0091-7613(1993)021\%3C0173:ccocoe\%3E2.3.co;2

667

668 Nokleberg, W.J., Parfenov, L.M., Monger, J.W.H., Norton, I.O., Khanchuk, A.I., Stone, D.B., 669 Scotese, C.R., Scholl, D.W., and Fujita, K. 2000. Phanerozoic tectonic evolution of the circum670 North Pacific. U. S. Geological Survey Professional Paper 1626, 1-133. doi.org/10.3133/pp1626

671

672 O’Dogherty, L., Carter, E.S., Dumitrica, P., Goričan, S., De Wever, P., Bandini, N.,

673 Baumgartner, P.O., and Matsuoka, A. 2009. Catalogue of Mesozoic radiolarian genera: Part 2.

674 Jurassic-Cretaceous. Geodiversitas, 31: 271-356. doi.org/10.5252/g2009n2a4

675

676 Orchard, M.J. 1981. Triassic conodonts from the Cache Creek Group, Marble Canyon, southern

677 British Columbia. In Current Research, Part A. Geological Survey of Canada, Paper 81-1A, pp.

$678 \quad 357-359$. doi.org/10.4095/109559

679

680 Orchard, M.J. 1984. Pennsylvanian, Permian, and Triassic conodonts from the Cache Creek

681 Group, southern British Columbia. In Current Research, Part B. Geological Survey of Canada, 682 Paper 84-1B, pp. 197-206. doi.org/10.4095/119575

683

684 Orchard, M.J., Cordey, F., Rui, L., Bamber, W., Struik, L.C., and Sano, H. 2001. Paleontological 685 constraints on the paleogeography of the Carboniferous to Jurassic Cache Creek Terrane in 
Pavlis, T. L., Amato, J. M., Trop, J. M., Ridgway, K. D., Roeske, S. M., and Gehrels, G. E. 2019.

690 Subduction polarity in ancient arcs: A call to integrate geology and geophysics to decipher the 691 Mesozoic tectonic history of the Northern Cordillera of North America. GSA Today: 29: 4-10. 692 doi.org/10.1130/gsatg402a.1

693

694 Piercey, S.J., and Colpron, M. 2009. Composition and provenance of the Snowcap assemblage, 695 basement to the Yukon-Tanana Terrane, northern Cordillera; implications for Cordilleran crustal 696 growth. Geosphere, 5: 439-464. doi.org/10.1130/ges00505.s3

697

698 Read, P.B. 1993. Geology of northeast Taseko Lakes map area, southwestern British Columbia. 699 In Current Research, Part A. Geological Survey of Canada, Paper 93-1A, pp. 159-166.

700 doi.org/10.4095/134202

701

702 Ricketts, B.D., Evenchick, C.A., Anderson, R.G., and Murphy, D.C. 1992. Bowser basin, 703 northern British Columbia: Constraints on the timing of initial subsidence and Stikinia-North 704 America terrane interactions. Geology, 20: 1119-1122. doi.org/10.1130/00917613(1992)020\%3C1119:bbnbcc\%3E2.3.co;2 doi.org/10.4095/109616 
711 Sigloch, K., and Mihalynuk, M.G. 2013. Intra-oceanic subduction shaped the assembly of

712 Cordilleran North America. Nature, 496: 50-56. doi.org/10.1038/nature12019

713

714 Sigloch, K., and Mihalynuk, M.G. 2017. Mantle and geological evidence for a Late Jurassic-

715 Cretaceous suture spanning North America. Geological Society of America Bulletin, 129: 1489-

716 1520. doi.org/10.1130/abs/2017am-306159

717

718 Struik, L C. 1998. Bedrock geology, Tezzeron, British Columbia; Geological Survey of Canada,

719 Open File 3624, 1 sheet. doi.org/10.4095/209920

720

721 Struik, L.C., Floriet, C., and Cordey, F. 1996. Geology near Fort St. James, central British

722 Columbia. In Current research, Part A. Geological Survey of Canada, Paper 96-A, pp. 71-76.

723 doi.org/10.4095/207411

724

725 Struik, L.C., Schiarizza, P., Orchard, M.J., Cordey, F., Sano, H., MacIntyre, D.G., Lapierre, H., 726 and Tardy, M. 2001. Imbricate architecture of upper Paleozoic to Jurassic oceanic Cache Creek

727 Terrane, central British Columbia. Canadian Journal of Earth Sciences, 38: 495-514.

728 doi.org/10.1139/e00-117

729

730 Struik, L.C., MacIntyre, D.G., and Williams, S.P. 2007. Nechako NATMAP Project: A digital

731 suite of geoscience information for central British Columbia Geological Survey of Canada, Open

732 File 5623. doi.org/10.4095/224578

733

734 Travers, W.B. 1978. Overturned Ashcroft and Nicola strata and their relation to the Cache Creek

735 Group, southwestern Intermontane Belt, British Columbia. Canadian Journal of Earth Sciences, 
738 Trettin, H.P. 1980. Permian rocks of the Cache Creek Group in the Marble Range, Clinton area, 739 British Columbia. Geological Survey of Canada, Paper 79-17, pp 1-17. doi.org/10.4095/106637 740

741 Umhoefer, P.J., and Schiarizza, P. 1996. Latest Cretaceous to early Tertiary dextral strike-slip 742 faulting on the southeastern Yalakom fault system, southeastern Coast Belt, British Columbia.

743 Geological Society of America Bulletin, 108: 768-785. doi.org/10.1130/0016-

$7447606(1996) 108 \% 3 C 0768: 1 c t e t d \% 3 E 2.3 . c o ; 2$

745

746 Whalen, P. A., and Carter, E. S. 2002. Pliensbachian (Lower Jurassic) Radiolaria from Baja

747 California Sur, Mexico. Micropaleontology, 48: 97-151. doi.org/10.1661/0026-

$748 \quad$ 2803(2002)048[0097:pljrfb]2.0.co;2

749

750 Wheeler, J.O., Brookfield, A.J., Gabrielse, H., Monger, J.W.H., Tipper, H.W., and Woodsworth, 751 G.J. 1991. Terrane map of the Canadian Cordillera. Geological Survey of Canada, Map 1713A, 752 1:2,000,000. doi.org/10.4095/133550

753

754 Zagorevski, A., Bedard, J.H., Bogatu, A., Coleman, M., Golding, M., and Joyce, N. 2017.

755 Stikinia bedrock report of activities, British Columbia and Yukon: GEM 2 Cordillera. Geological 756 Survey of Canada, Open File 8329, pp. 1-15. doi.org/10.4095/306144 
757 Table 1. Jurassic radiolarian taxa and ages from the Cache Creek Terrane

\begin{tabular}{|c|c|c|c|c|c|c|}
\hline $\begin{array}{l}\text { Locality, } \\
\text { Region }\end{array}$ & $\begin{array}{l}\text { Subterrane or unit, } \\
\text { map area \& UTM } \\
\text { coordinates }\end{array}$ & $\begin{array}{l}\text { Lithology, } \\
\text { Sample, GSC } \\
\text { locality number } \\
\text { when available }\end{array}$ & Radiolarian assemblage & $\begin{array}{l}\text { Original age, } \\
\text { Reference(s) }\end{array}$ & $\begin{array}{l}\text { New or revised } \\
\text { age }\end{array}$ & $\begin{array}{l}\text { Generic assemblage or } \\
\text { correlation to biozones } \\
\text { (when applicable) }\end{array}$ \\
\hline $\begin{array}{l}\text { J1 } \\
\text { southern } \\
\text { British } \\
\text { Columbia }\end{array}$ & $\begin{array}{l}\text { western belt } \\
\text { Pavilion } \\
\text { NTS 092/13 } \\
\text { UTM zone } 10 \\
581045 \mathrm{E} \\
5646753 \mathrm{~N}\end{array}$ & $\begin{array}{l}\text { siliceous argillite } \\
\text { NEO-R2 } \\
\text { GSC C-300438 } \\
\text { (previously R2, } \\
\text { Cordey et al. } \\
\text { 1987, Cordey } \\
\text { 1998) }\end{array}$ & $\begin{array}{l}\text { Archaeodictyomitra sp., } \\
\text { Homoeoparonaella sp. cf. } \\
\text { reciproqua, Hsuum sp., } \\
\text { Pseudocrucella? sp., Thurstonia sp., } \\
\text { Trillus sp., Xiphostylus? sp., Zartus } \\
\text { sp. }\end{array}$ & $\begin{array}{l}\text { Early Jurassic } \\
\text { (Pliensbachian- } \\
\text { Bajocian) } \\
\text { (Cordey et al. } \\
\text { 1987, Cordey } \\
\text { 1998) }\end{array}$ & $\begin{array}{l}\text { Early Jurassic } \\
\text { (Early } \\
\text { Pliensbachian - } \\
\text { Early Toarcian) }\end{array}$ & $\begin{array}{l}\text { Co-occurrence of } \\
\text { Thurstonia, Trillus and } \\
\text { Zartus (O'Dogherty et al. } \\
\text { 2009) }\end{array}$ \\
\hline $\begin{array}{l}\text { J2 } \\
\text { southern } \\
\text { British } \\
\text { Columbia }\end{array}$ & $\begin{array}{l}\text { western belt } \\
\text { Alkali Lake } \\
\text { NTS } 092016 \\
\text { UTM zone } 10 \\
548240 \mathrm{E} \\
5749410 \mathrm{~N}\end{array}$ & $\begin{array}{l}\text { gray-green } \\
\text { radiolarian chert } \\
\text { 92-PBR-C92-78F } \\
\text { GSC C-210033 }\end{array}$ & $\begin{array}{l}\text { Canutus sp., Lantus sp., } \\
\text { Orbiculiformella sp., Parahsuum sp., } \\
\text { Praeconocaryomma sp. }\end{array}$ & $\begin{array}{l}\text { Early Jurassic } \\
\text { (Sinemurian- } \\
\text { Pliensbachian) } \\
\text { (Cordey, unp. } \\
\text { data; Read } \\
\text { 1993) }\end{array}$ & $\begin{array}{l}\text { Early Jurassic } \\
\text { (Early } \\
\text { Pliensbachian - } \\
\text { Early Toarcian) }\end{array}$ & $\begin{array}{l}\text { Co-occurrence of } \\
\text { Canutus and Lantus } \\
\text { (O'Dogherty et al. 2009) }\end{array}$ \\
\hline $\begin{array}{l}\text { J3 } \\
\text { central } \\
\text { British } \\
\text { Columbia }\end{array}$ & $\begin{array}{l}\text { Blackwater River } \\
\text { Punchaw Lake } \\
\text { NTS 093G6 } \\
\text { UTM zone } 10 \\
490750 \text { E } \\
5904150 \mathrm{~N}\end{array}$ & $\begin{array}{l}\text { gray radiolarian } \\
\text { chert } \\
\text { 95FC-21-4 } \\
\text { GSC C-303032 }\end{array}$ & $\begin{array}{l}\text { Atalantria sp., Beatricea? } \\
\text { argescens, Bipedis japonicus, } \\
\text { Broctus sp., Broctus? sp., } \\
\text { Canoptum rugosum, Canoptum sp. } \\
\text { cf. dixoni, Charlottea sp., Katroma } \\
\text { sp. cf. elongata, Lantus sp. cf. } \\
\text { praeobesus, Laxtorum sp., } \\
\text { Orbiculiformella? trispina s.l. (Yeh), } \\
\text { Orbiculiformella sp., } \\
\text { Palaeosaturnalis sp., Parahsuum } \\
\text { simplum, Parahsuum vizcainoense, } \\
\text { Praeconocaryomma sp. cf. sarahae, } \\
\text { Thurstonia sp., Spumellaria gen. sp. } \\
\text { indet. }\end{array}$ & $\begin{array}{l}\text { Early Jurassic } \\
\text { (Pliensbachian) } \\
\text { (Cordey and } \\
\text { Struik 1996, } \\
\text { Orchard et al. } \\
\text { 2001) }\end{array}$ & $\begin{array}{l}\text { Early Jurassic } \\
\text { (Early } \\
\text { Pliensbachian) }\end{array}$ & $\begin{array}{l}\text { Interval from the middle } \\
\text { part of the Canutus tipperi } \\
\text { - Katroma clara Zone to } \\
\text { the base of the Gigi fustis } \\
\text { - Lantus sixi Zone } \\
\text { (Unitary associations UA } \\
\text { 04-12) (Carter et al. } \\
\text { 2010). }\end{array}$ \\
\hline $\begin{array}{l}\text { J4 } \\
\text { central } \\
\text { British } \\
\text { Columbia }\end{array}$ & $\begin{array}{l}\text { Tezzeron } \\
\text { succession } \\
\text { Pinchi Lake } \\
\text { NTS 093K9 } \\
\text { UTM zone 10, } \\
418200 \mathrm{E} \\
6049406 \mathrm{~N}\end{array}$ & $\begin{array}{l}\text { limy siltstone } \\
\text { 97-SCB-3602 } \\
\text { GSC C-209935 }\end{array}$ & $\begin{array}{l}\text { Emiluvia? sp. A, Hsuum lucidum, } \\
\text { Paronaella grahamensis, } \\
\text { Praeconocaryomma decora gr., } \\
\text { Praeparvicingula tlellensis }\end{array}$ & $\begin{array}{l}\text { Early Jurassic } \\
\text { (Toarcian) } \\
\text { (Struik et al. } \\
\text { 2001, Orchard } \\
\text { et al. 2001) }\end{array}$ & $\begin{array}{l}\text { Early Jurassic } \\
\text { (Middle - Late } \\
\text { Toarcian) }\end{array}$ & $\begin{array}{l}\text { Interval represented by } \\
\text { the Elodium pessagnoi- } \\
\text { Hexasaturnalis } \\
\text { hexagonus Zone (Carter } \\
\text { et al. 2010) }\end{array}$ \\
\hline $\begin{array}{l}\text { J5 } \\
\text { northern } \\
\text { British } \\
\text { Columbia }\end{array}$ & $\begin{array}{l}\text { French Range } \\
\text { Little Dease Lake } \\
\text { NTS 104J09 } \\
\text { UTM zone 10, } \\
\text { 419000E } \\
6508000 \mathrm{~N}\end{array}$ & $\begin{array}{l}\text { siliceous argillite } \\
\text { MMI99-34-12 }\end{array}$ & $\begin{array}{l}\text { Parahsuum izeense, } \\
\text { Orbiculiformella? trispina s.l., } \\
\text { Praeconocaryomma sp. cf. sarahae, } \\
\text { Praeconocaryomma sp., Thurstonia } \\
\text { sp. }\end{array}$ & $\begin{array}{l}\text { Early Jurassic } \\
\text { (Pliensbachian- } \\
\text { Toarcian) } \\
\text { (Mihalynuk et } \\
\text { al. 2004) }\end{array}$ & $\begin{array}{l}\text { Early Jurassic } \\
\text { (Pliensbachian - } \\
\text { Early Toarcian) }\end{array}$ & $\begin{array}{l}\text { Co-occurrence of } \\
\text { Parahsuum izeense and } \\
\text { Thurstonia (Carter et al. } \\
\text { 2010, O'Dogherty et al. } \\
\text { 2009). }\end{array}$ \\
\hline $\begin{array}{l}\text { J6 } \\
\text { Yukon }\end{array}$ & $\begin{array}{l}\text { Teslin Plateau } \\
\text { Mount Bryde } \\
\text { NTS } 105 \mathrm{C} 03 \\
\text { UTM zone 10, } \\
599028 \mathrm{E} \\
6676847 \mathrm{~N}\end{array}$ & $\begin{array}{l}\text { siliceous argillite } \\
\text { interbedded with } \\
\text { sandstone } \\
\text { 90FC-56-6 } \\
\text { GSC C-177569 }\end{array}$ & $\begin{array}{l}\text { Bipedis sp., Broctus sp., Canoptum } \\
\text { anulatum, Canoptum sp., } \\
\text { Hagiastrum majusculum, } \\
\text { Homoeoparonaella sp., Lantus sixi, } \\
\text { Napora cerromesaensis, } \\
\text { Pantanellium cumshewaense, } \\
\text { Parahsuum izeense, } \\
\text { Praeconocaryomma? sp. cf. } \\
\text { yakounensis, Thurstonia sp., } \\
\text { Wrangellium sp. }\end{array}$ & $\begin{array}{l}\text { Early Jurassic } \\
\text { (Pliensbachian- } \\
\text { Early Toarcian) } \\
\text { (Cordey et al. } \\
\text { 1991) }\end{array}$ & $\begin{array}{l}\text { Early Jurassic } \\
\text { (late Early } \\
\text { Pliensbachian - } \\
\text { Late } \\
\text { Pliensbachian) }\end{array}$ & $\begin{array}{l}\text { Interval from the base of } \\
\text { the Gigi fustis - Lantus } \\
\text { sixi Zone to the middle } \\
\text { part of the Eucyrtidiellum } \\
\text { nagaiae - } \\
\text { Praeparvicingula tlellensis } \\
\text { Zone (Unitary } \\
\text { associations UA 12-22; } \\
\text { Carter et al. 2010) }\end{array}$ \\
\hline $\begin{array}{l}\text { J7 } \\
\text { Yukon }\end{array}$ & $\begin{array}{l}\text { Teslin Plateau } \\
\text { Mount Bryde } \\
\text { NTS } 105 \mathrm{C} 03 \\
\text { UTM zone 10, } \\
600094 \mathrm{E} \\
6673025 \mathrm{~N}\end{array}$ & $\begin{array}{l}\text { black radiolarian } \\
\text { chert } \\
\text { 90FC-63-2 } \\
\text { GSC C-177580 }\end{array}$ & $\begin{array}{l}\text { Beatricea? argescens, Canoptum } \\
\text { sp. cf. anulatum, Canoptum sp., } \\
\text { Praeconocaryomma sp. cf. } \\
\text { immodica, Wrangellium sp. }\end{array}$ & $\begin{array}{l}\text { Early Jurassic } \\
\text { (Sinemurian- } \\
\text { Toarcian) } \\
\text { (Cordey et al. } \\
\text { 1991) }\end{array}$ & $\begin{array}{l}\text { Early Jurassic } \\
\text { (Late Sinemurian } \\
\text { - Late } \\
\text { Pliensbachian) }\end{array}$ & $\begin{array}{l}\text { Co-occurrence of } \\
\text { Beatricea and } \\
\text { Wrangellium (O'Dogherty } \\
\text { et al. 2009) }\end{array}$ \\
\hline $\begin{array}{l}\text { J8 } \\
\text { Yukon }\end{array}$ & $\begin{array}{l}\text { Teslin Plateau } \\
\text { Mount Bryde } \\
\text { NTS 105C03 } \\
\text { UTM zone 10, } \\
600094 \mathrm{E} \\
6673025 \mathrm{~N}\end{array}$ & $\begin{array}{l}\text { dark gray } \\
\text { radiolarian chert } \\
\text { 90FC-63-9 } \\
\text { GSC C-177587 }\end{array}$ & $\begin{array}{l}\text { Beatricea? argescens, Bipedis sp., } \\
\text { Canoptum sp. cf. dixoni, } \\
\text { Gorgansium sp., Pantanellium sp., } \\
\text { Parahsuum sp., } \\
\text { Praeconocaryomma sp., } \\
\text { Wrangellium sp. }\end{array}$ & $\begin{array}{l}\text { Early Jurassic } \\
\text { (Sinemurian- } \\
\text { Toarcian) } \\
\text { (Cordey et al. } \\
\text { 1991) }\end{array}$ & $\begin{array}{l}\text { Early Jurassic } \\
\text { (Late Sinemurian } \\
\text { - Late } \\
\text { Pliensbachian) }\end{array}$ & $\begin{array}{l}\text { Co-occurrence of } \\
\text { Beatricea, Bipedis, and } \\
\text { Wrangellium (O'Dogherty } \\
\text { et al. 2009) }\end{array}$ \\
\hline
\end{tabular}


760 Figure 1 (colour online and printed). Paleozoic to early Mesozoic terranes of the Canadian

761 Cordillera and location of the Cache Creek Terrane. Modified from Piercey and Colpron (2009).

762

763

Figure 2. Geographic location of Jurassic radiolarian assemblages from the Cache Creek Terrane

764 (J1 to J8, Table 1). Black frame: Fig. 3a (type locality of the terrane).

765

766

Figure 3. a: Distribution of Paleozoic and Mesozoic rock units in the type locality of the Cache

767 Creek Terrane and position of the study area for locality J1 (Fig. 2). Geology from Monger

768 (1985). b: Geological map of the Pavilion area and location of the Early Jurassic radiolarian 769 sample NEO-R2. Geology from Monger and McMillan (1984), Mortimer (1987), and Cordey et 770 al. (1987).

771

772 Figure 4. Synthetic lithostratigraphic successions of the Cache Creek Terrane in its type locality 773 (southern British Columbia). The locality numbers (C-) refer to the Geological Survey of Canada 774 database and the radiolarian localities from Cordey (1998). Black lines (eastern belt): age of 775 blocks (Cache Creek mélange). Conodont data from Orchard (1981, 1984), Beyers and Orchard 776 (1989, 1991); fusulinid data from Monger and Ross (1971). Geological time scale from Cohen et 777 al. (2013). G: Guadalupian; L: Lopingian. LO: Lower.

779 Figure 5. Early Jurassic radiolarians from the Cache Creek Terrane. For each picture: taxon, 780 sample, locality (Table 1), length of scale bar. 1. Thurstonia sp., NEO-R2, J1, $150 \mu \mathrm{m}$. White 781 arrows point to fifth and sixth spines. 2. Thurstonia? sp., NEO-R2, J1, $170 \mu \mathrm{m}$. 3-7: Thurstonia 782 sp.; 3-5: 90FC-56-6, J6, $160 \mu \mathrm{m} ; 6$ : MMI99-34-12, J5, $110 \mu \mathrm{m} ;$ 7: 90FC-56-6, J6, $180 \mu \mathrm{m}$. White 
783 arrows point to sixth spine. 8-9. Spumellaria gen. sp. indet., 95FC-21-4, J3, 165 and $140 \mu \mathrm{m} .10$.

784 Pantanellium cumshewaense Pessagno \& Blome, 90FC-56-6, J6, 110 m. 11-12. Trillus spp., 785 NEO-R2, J1, $120 \mu \mathrm{m}$. 13. Zartus sp., NEO-R2, J1, $115 \mu \mathrm{m}$. 14. Charlottea sp., 95FC-21-4, J3, $786115 \mu \mathrm{m}$. 15. Palaeosaturnalis sp., 95FC-21-4, J3, $160 \mu \mathrm{m}$. 16. Hagiastrum majusculum Whalen 787 \& Carter, 90FC-56-6, J6, $170 \mu \mathrm{m} .17$. Homoeoparonaella sp. cf. reciproqua Carter, NEO-R2, J1, $220 \mu \mathrm{m} .18$. Homoeoparonaella sp., 90FC-56-6, J6, $140 \mu \mathrm{m} .19$. Orbiculiformella sp., 95FC-214, J3, $170 \mu \mathrm{m}$. 20. Orbiculiformella? trispina s.1. (Yeh), 95FC-21-4, J3, $150 \mu \mathrm{m} .21$. Beatricea? argescens Cordey, 90FC-63-2, J7, $160 \mu \mathrm{m} .22$. Praeconocaryomma? sp. cf. yakounensis Carter, 90FC-56-6, J6, $150 \mu \mathrm{m}$. 23-24. Praeconocaryomma sp. cf. sarahae Carter; 23: 95FC-21-4, J3, $130 \mu \mathrm{m} ; 24:$ MMI99-34-12, J5, $160 \mu \mathrm{m}$.

Figure 6. Early Jurassic radiolarians from the Cache Creek Terrane. For each picture: taxon, sample, locality (Table 1), length of scale bar. 1. Lantus sixi Yeh, 90FC-56-6, J6, $110 \mu \mathrm{m} .2$. Lantus sp. cf. praeobesus Carter, 95FC-21-4, J3, $110 \mu \mathrm{m} .3$. Broctus sp., 95FC-21-4, J3, $100 \mu \mathrm{m}$. 4. Broctus sp., 90FC-56-6, J6, $130 \mu \mathrm{m}$. 5. Xiphostylus? sp., NEO-R2, J1, $140 \mu \mathrm{m}$. 6. Katroma sp. cf. elongata Carter, 95FC-21-4, J3, $150 \mu \mathrm{m}$. 7. Parahsuum vizcainoense Whalen \& Carter, 95FC-

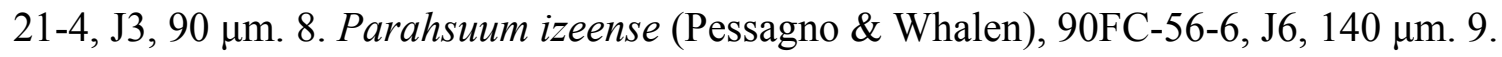
Canoptum sp., 95FC-21-4, J3, $100 \mu \mathrm{m}$. 10. Canoptum rugosum Pessagno \& Poisson, 95FC-21-4, J3, $90 \mu \mathrm{m}$. 11-12. Canoptum spp., 90FC-56-6, J6, $120 \mu \mathrm{m}$. 13. Broctus? sp., 95FC-21-4, J3, 110 $\mu \mathrm{m}$. 14. Canoptum sp. cf. anulatum Pessagno \& Poisson, 90FC-63-2, J7, $120 \mu \mathrm{m}$. 15. Canoptum sp. cf. dixoni Pessagno \& Whalen, 95FC-21-4, J3, 120 m. 16. Atalantria sp., 95FC-21-4, J3, 120

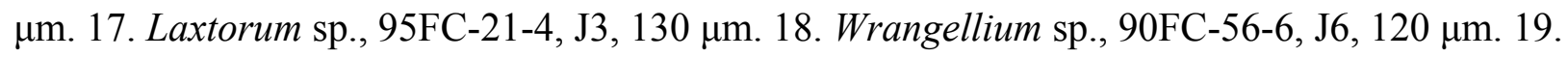
Hsuum sp., NEO-R2, J1, 110 m. 20. Archaeodictyomitra sp., NEO-R2, J1, $130 \mu$ m. 21. Bipedis sp., 90FC-56-6, J6, $110 \mu \mathrm{m}$. 22. Bipedis japonicus Hori, 95FC-21-4, J3, $130 \mu \mathrm{m}$. 23. Napora cerromesaensis Pessagno, Whalen \& Yeh, 90FC-56-6, J6, $105 \mu \mathrm{m}$. 
809 Figure 7. Synthesis of the youngest Jurassic radiolarian ages of the Cache Creek Terrane.

810 Previous age determinations: J1: Cordey et al. (1987), Cordey (1998); J2: Read (1993), Cordey

811 (unpub. data); J3: Cordey and Struik (1996), Orchard et al. (2001); J4: Struik et al. (2001),

812 Orchard et al. (2001); J5 : Mihalynuk et al. (2004); J6-J8 : Cordey et al. (1991).

814 Figure 8. Radiolarian age ranges and correlations of youngest Cache Creek strata in British 815 Columbia and Yukon. The hatched band materializes the youngest common age range of 816 siliceous rocks (radiolarian cherts and siliceous argillites); limy siltstones at J4 are not included in 817 the correlation. The gray band shows the hypothetical age range of the youngest siliceous 818 argillites overlying the youngest well-dated radiolarian cherts (J3, Early Pliensbachian). The 819 oblique line represents the maximum age difference of the youngest well-dated hemipelagic 820 rocks (siliceous argillites) between southern British Columbia (J1) and Yukon (J6); this interval 821 (late Early Pliensbachian to Early Toarcian) is $\sim 8$ m.y. ( 188-180 Ma, Cohen et al. 2013). 


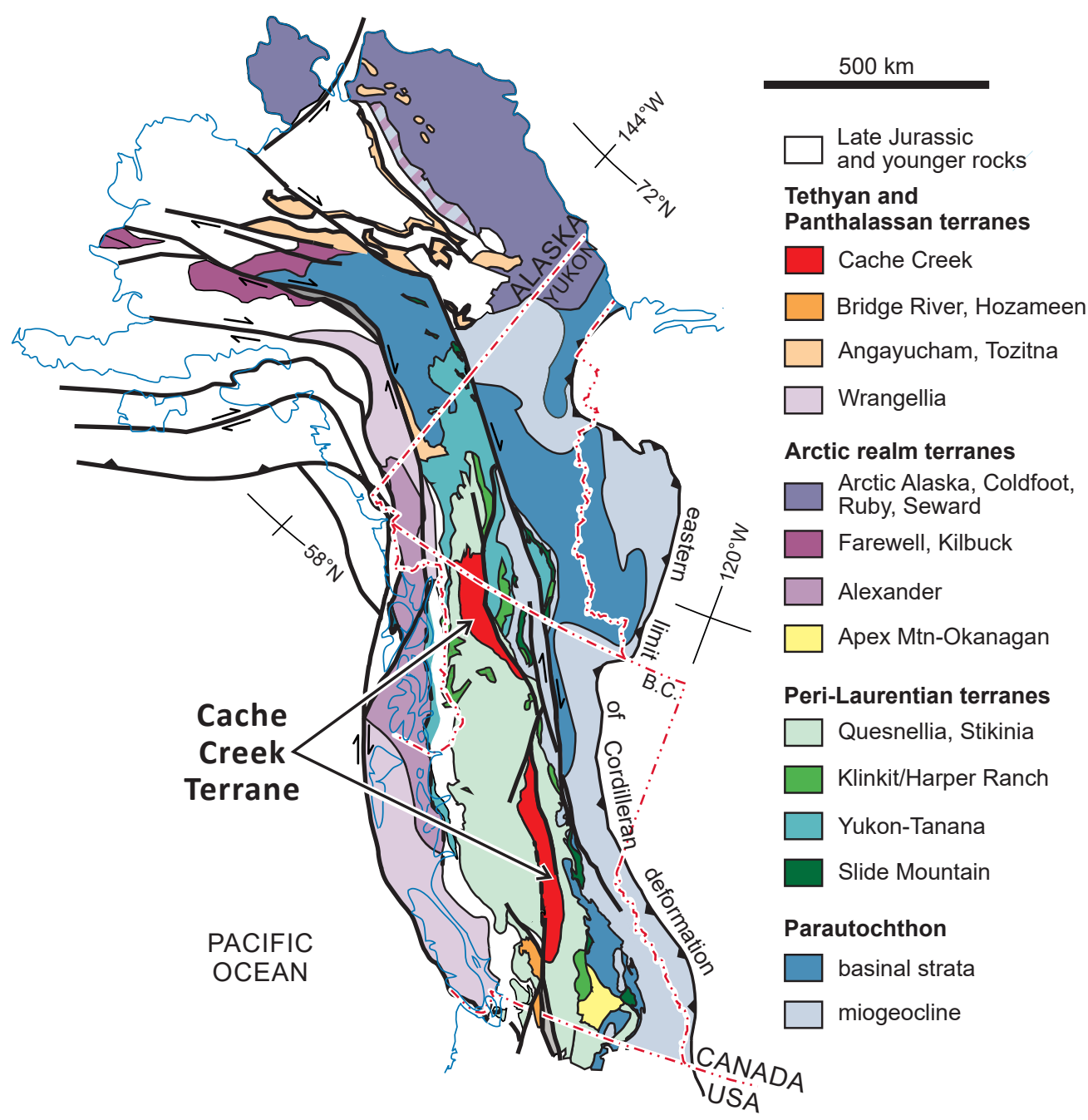

Figure 1 


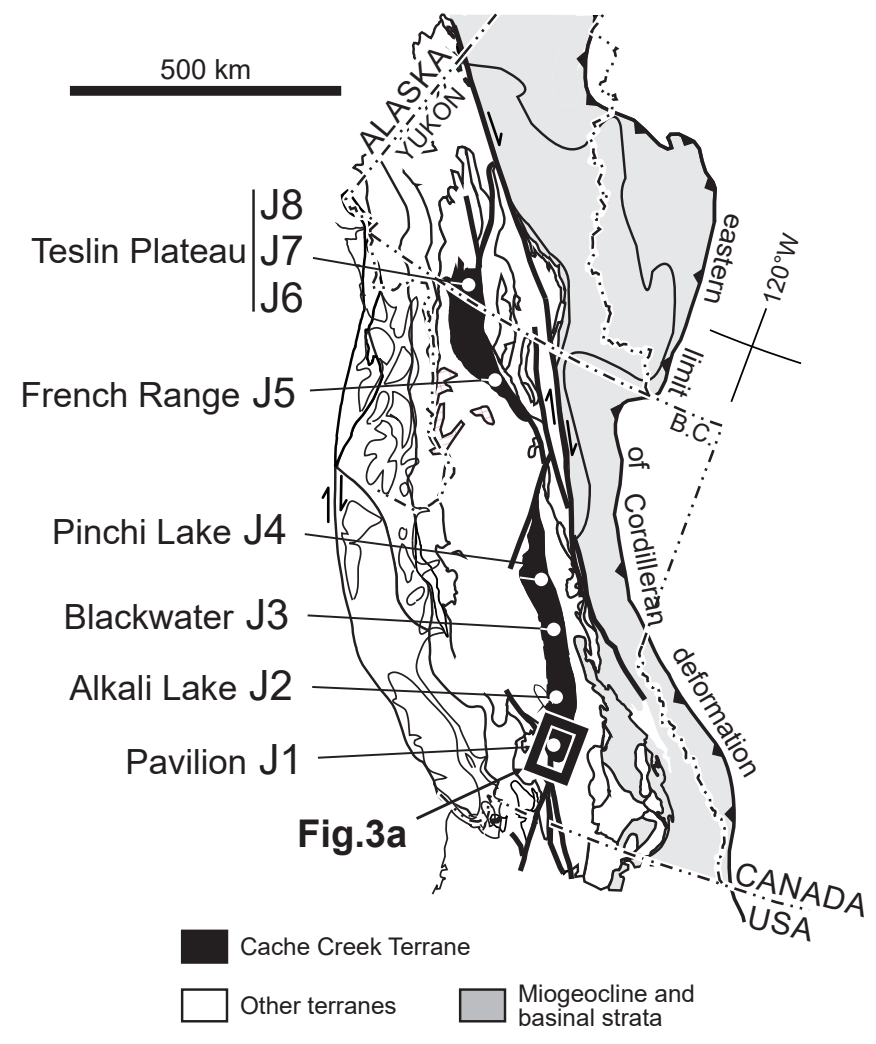

Figure 2 

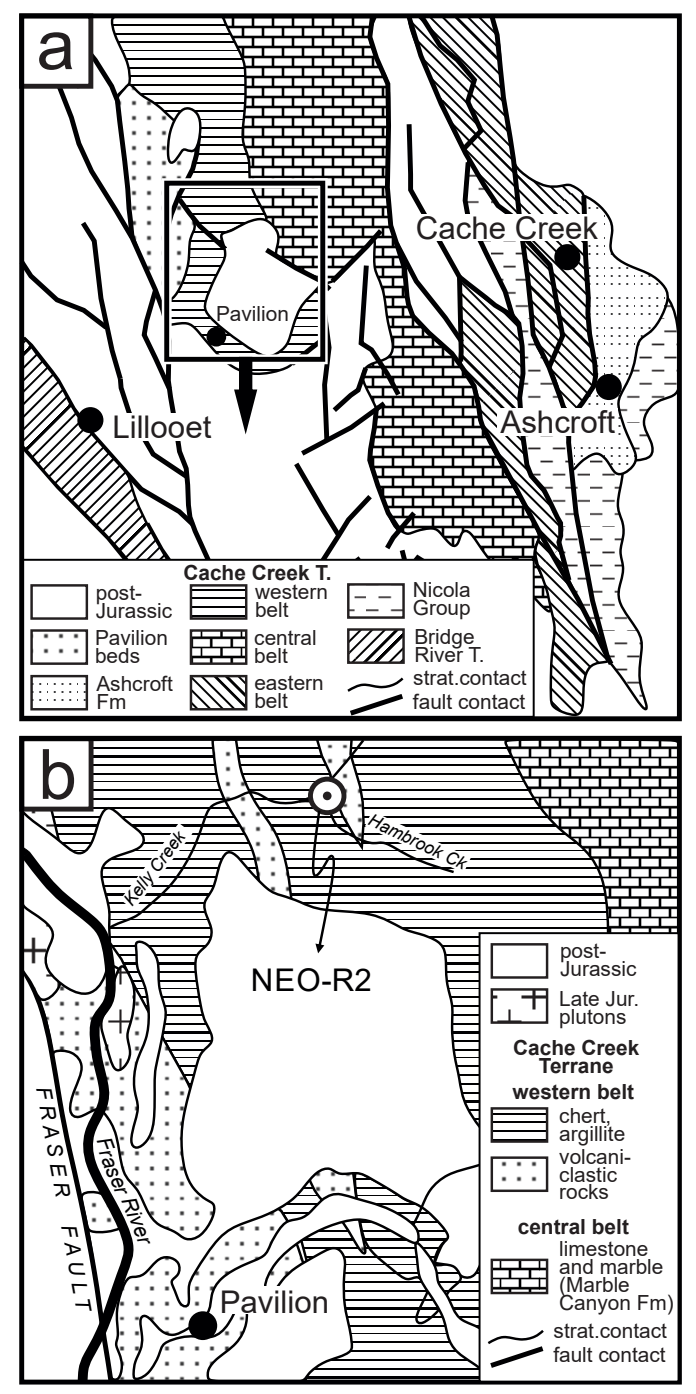

Figure 3 

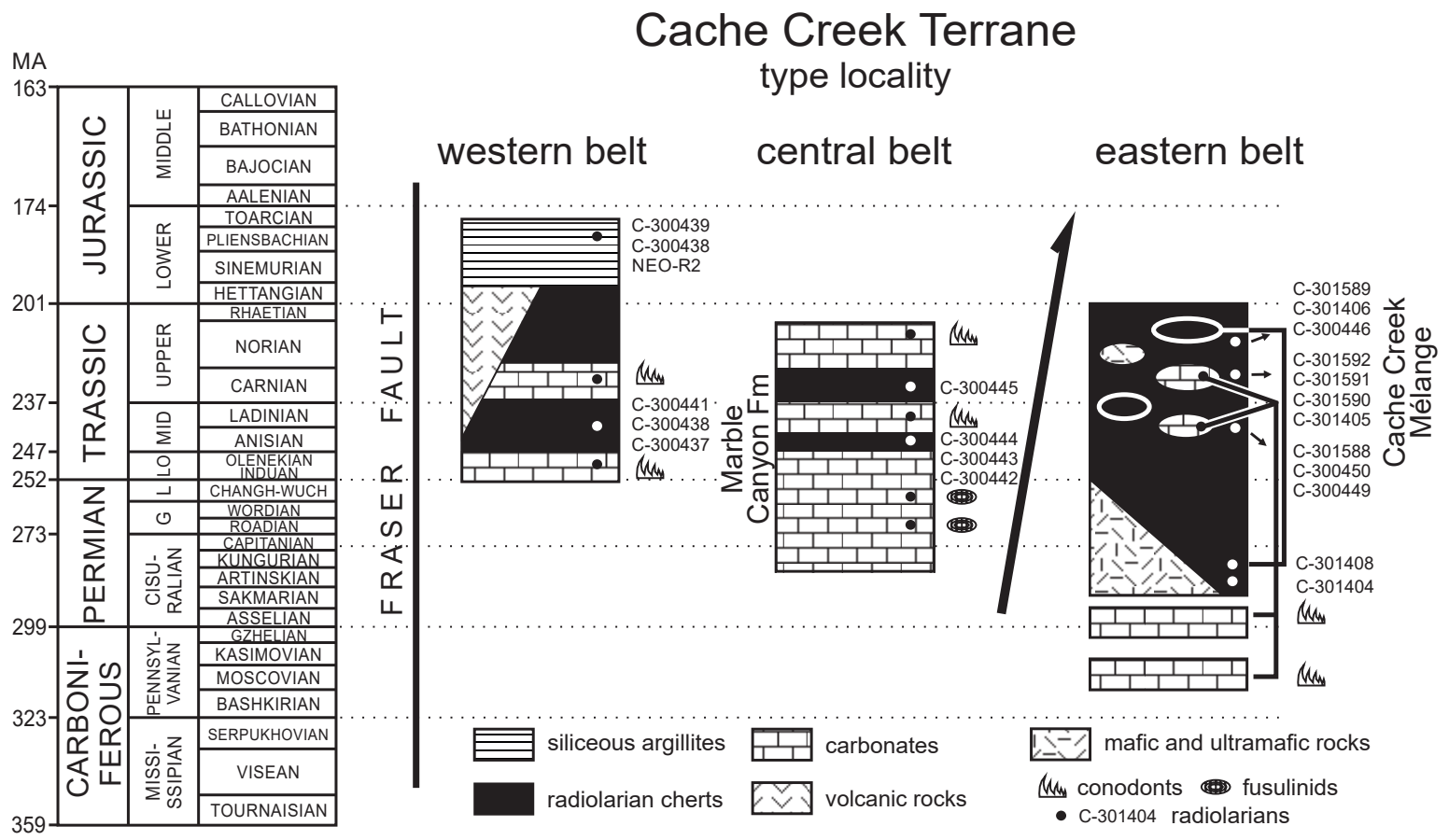

Figure 4 


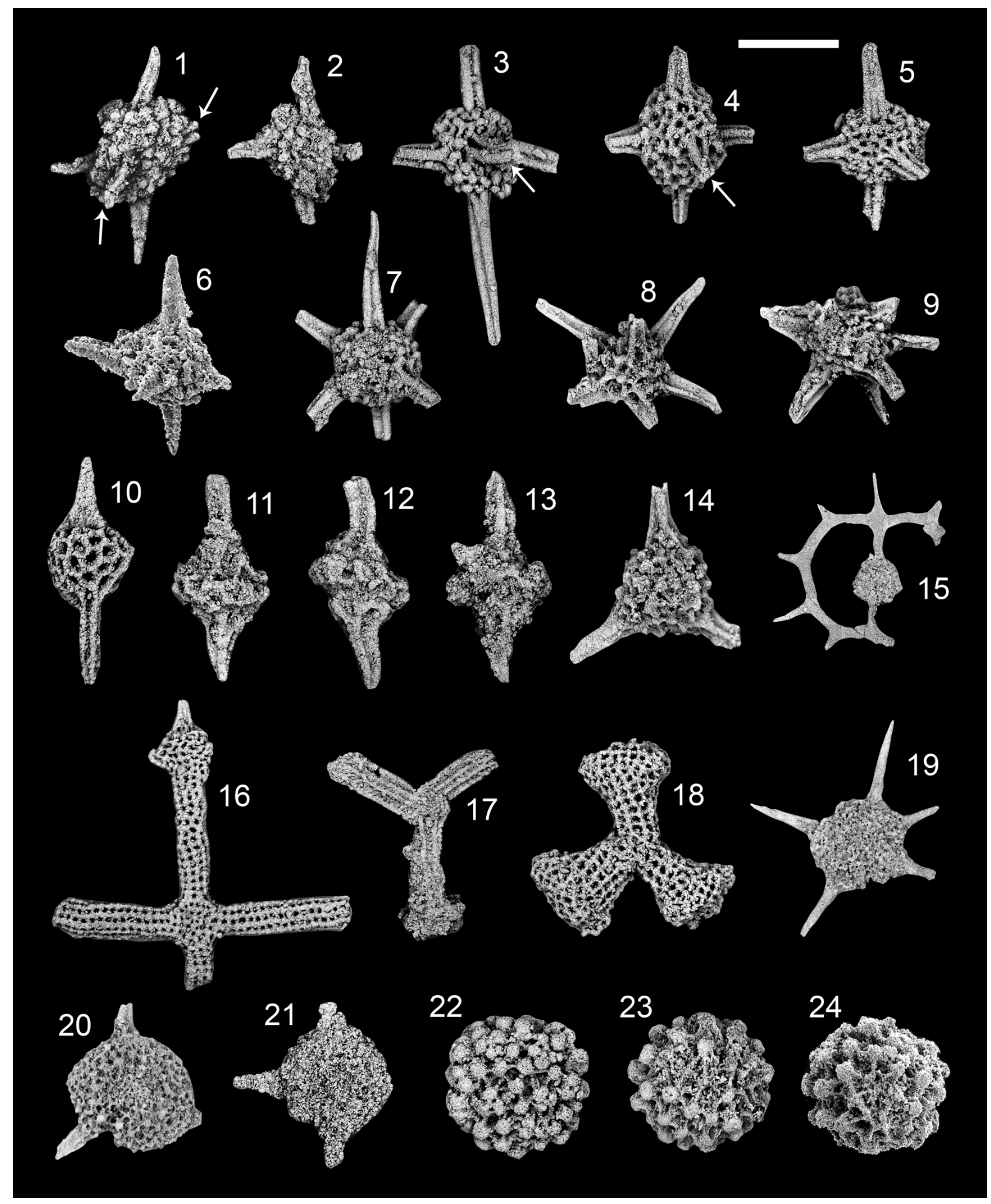

Figure 5 

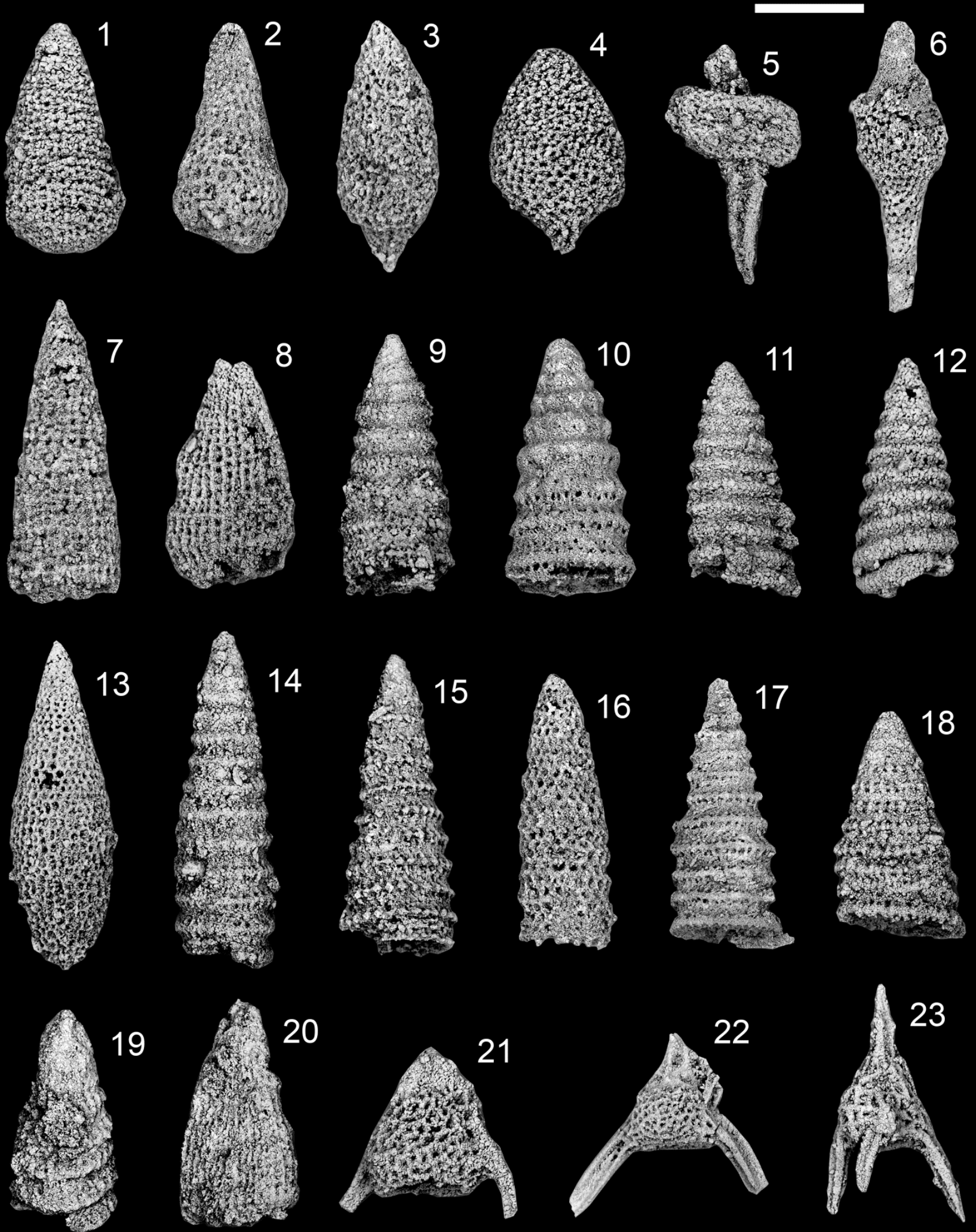

Figure 6 


\section{Cache Creek Terrane}

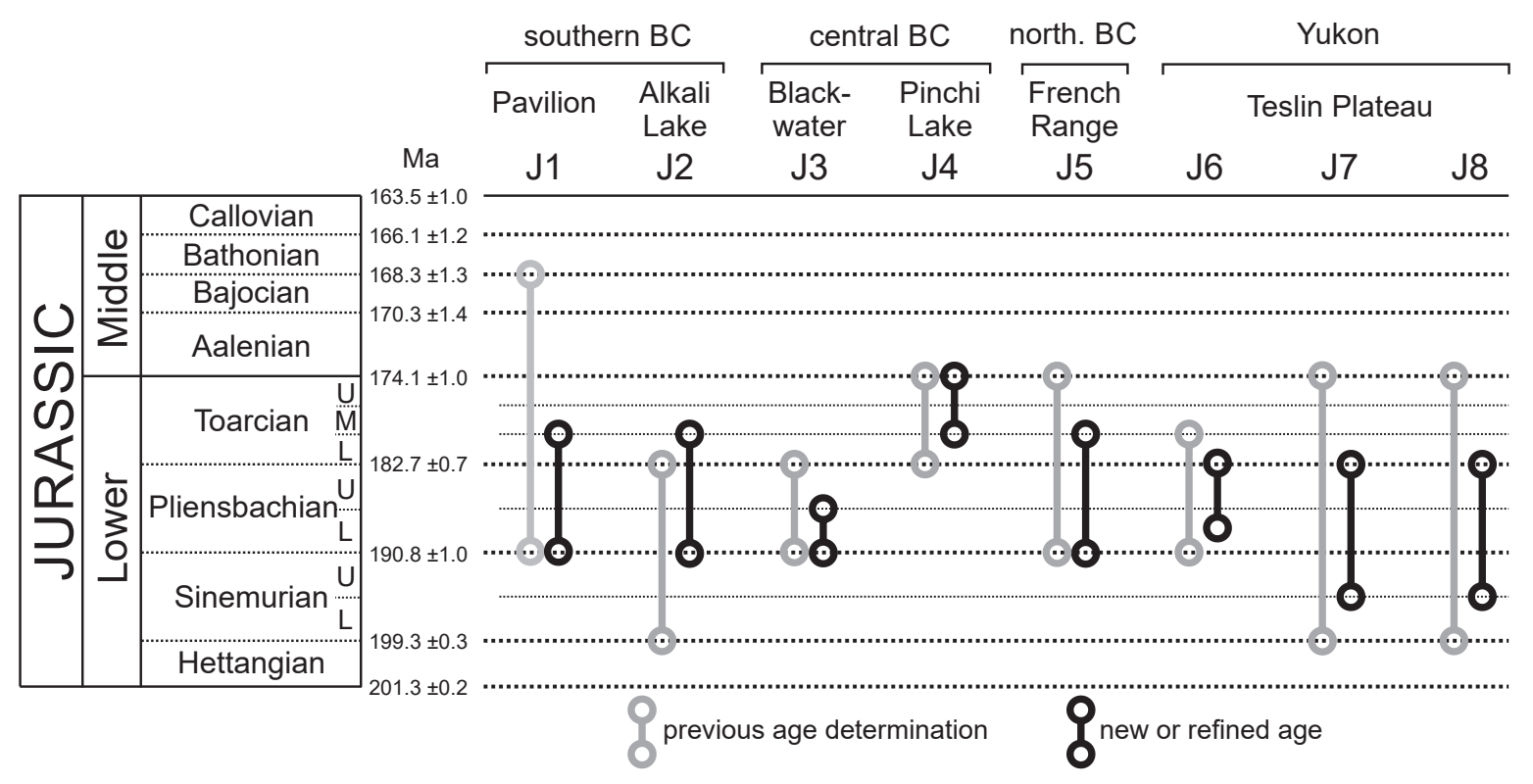

Figure 7 


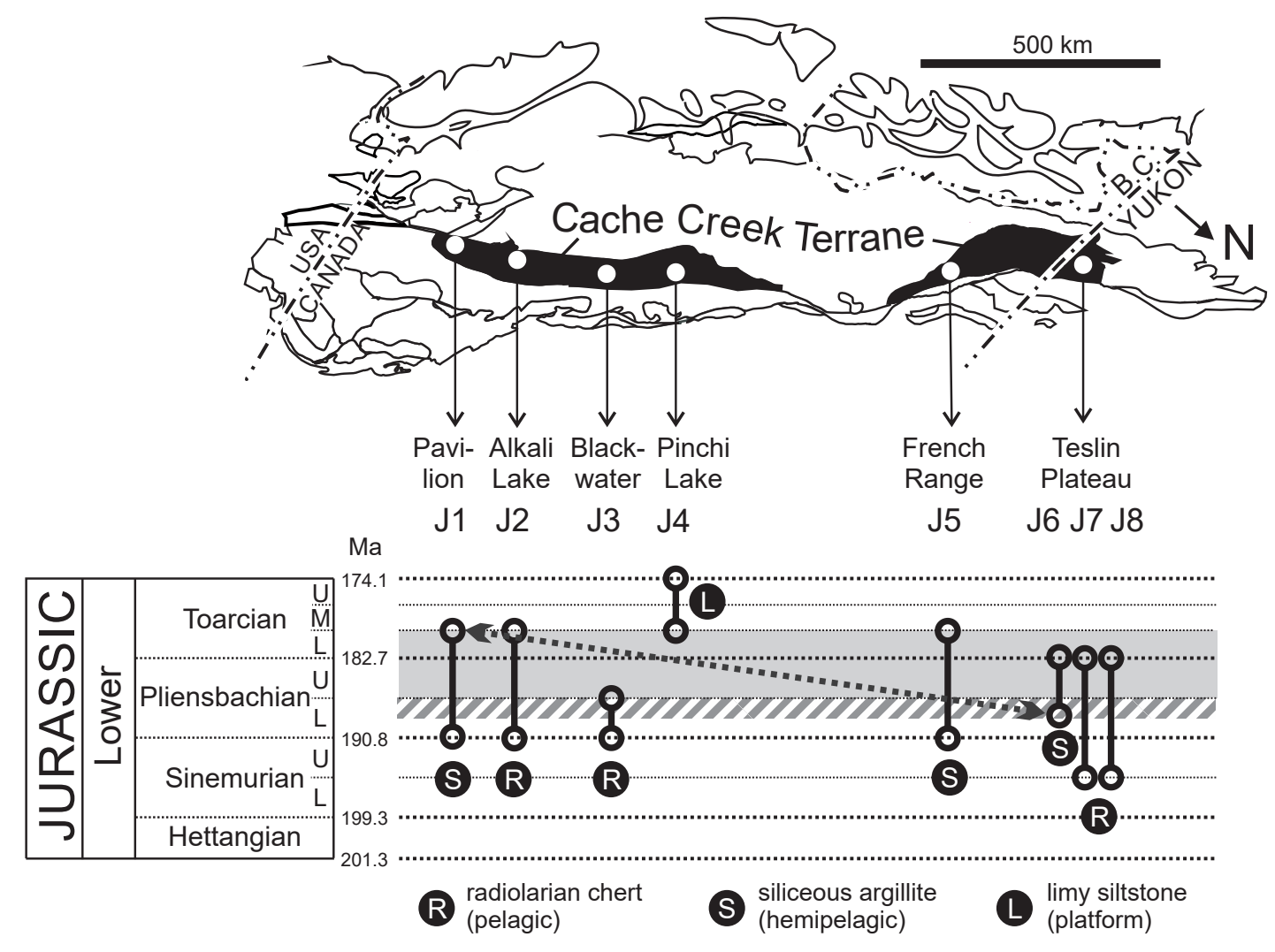

Figure 8 